\title{
DRAINMOD-LINKED INTERFACE FOR EVALUATING DRAINAGE SYSTEM RESPONSE TO CLIMATE SCENARIOS
}

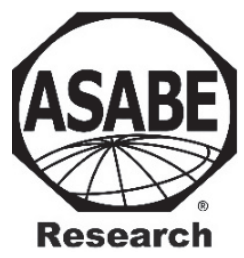

\author{
N. Adhikari, P. C. Davidson, R. A. Cooke, R. S. Book
}

\begin{abstract}
This article presents the development of a drainage-climate interface that incorporates climatological data, crop drainage requirements, and drainage theory into a procedure for characterizing drainage system response under different climate scenarios. The drainage-climate interface is suitable for assessing potential county-level impacts of climate change on crop production, soil hydrology and subsequently on subsurface drainage design. Climate model projections from two general circulation models (GCMs), namely CCSM4 (Community Climate System Model) and MIROC5 (Model for Interdisciplinary Research on Climate), were used to create the climatological database for the drainage-climate interface. DRAINMOD was integrated into the Visual Basic for Applications (VBA) portion of the interface to simulate the performance of subsurface drainage systems in Illinois for the near future (2040 to 2069) and the far future (2070 to 2099) periods. Case studies were developed with the interface for Adams and Champaign Counties in Illinois for their predominant soil types. Hydrologic simulations from the interface were used to determine the optimal depth and spacing of tile drains that maximize crop yield for corn and soybean during the mid and late $21^{\text {st }}$ century. Drainage water management (DWM) was incorporated into the drainage-climate interface to investigate the potential of DWM in the future climate scenarios to maintain water quality, reduce nutrient losses and minimize pollutant loading from drained fields by controlling the timing and amount of water discharged from agricultural drainage systems. Results from DRAINMOD simulations with MIROC5 show a significant decline in crop yield due to extreme heat stress. Corn yield in the future showed a severe reduction while the yield for soybean demonstrated a gradual decline over the years. DWM had only a minimal effect on future crop yield trends. The drainage-climate interface simulated subsurface drainage conditions and made evident the consequences of environmental conditions on crop physiological processes under scenarios of climate change predicted by MIROC5.
\end{abstract}

Keywords. Agricultural system models, Climate change impacts, Drainage-climate interface, Drainage water management, Subsurface drainage, Tile drain depth, Tile drain spacing.

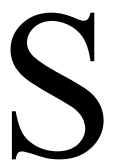
ubsurface drainage systems are necessary for agricultural production in areas with poorly drained soils. These systems remove excess water in the soil, protect crops from saturation stress or high-water table conditions and allow for timely seedbed preparation, planting and harvesting (Skaggs et al., 1994).

\footnotetext{
(c) (1) $\$$ The authors have paid for open access for this article. This

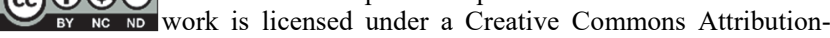
NonCommercial-NoDerivatives 4.0 International License https://creative commons.org/licenses/by-nc-nd/4.0/.

Submitted for review in February 2019 as manuscript number NRES 13383; approved for publication as a Research Article by the Natural Resources \& Environmental Systems Community of ASABE in March 2020.

Mention of company or trade names is for description only and does not imply endorsement by the USDA. The USDA is an equal opportunity provider and employer.

The authors are Nidhi Adhikari, Graduate Student, Paul C. Davidson, Associate Professor, and Richard A. Cooke, Professor, Department of Agricultural and Biological Engineering, University of Illinois UrbanaChampaign, Illinois; Ruth S. Book, Illinois State Conservation Engineer, USDA-NRCS, Champaign, Illinois. Corresponding author: Paul C. Davidson, 1304 W Pennsylvania, 360 E Agricultural Engineering Sciences Building, Urbana, IL 61801; phone: 217-300-3755; email: pdavidso@illinois.edu.
} 
The design of subsurface drainage systems is affected by climatic variables such as temperature and precipitation, as these variables impact hydrology as well as crop production (Singh et al., 2009). According to the Intergovernmental Panel on Climate Change (IPCC, 2014), climatic conditions are likely to change in the coming decades due to an increase in the atmospheric concentration of greenhouse gases (GHGs), with global impacts on agriculture. An accelerated warming trend is projected, with temperatures increasing by $3^{\circ} \mathrm{C}$ to $6^{\circ} \mathrm{C}$, while a $10 \%$ to $30 \%$ increase in annual precipitation may occur across the Midwestern United States by the end of the $21^{\text {st }}$ century (Easterling and Karl, 2001; Wuebbles and Hayhoe, 2004). Current drainage systems in Illinois are designed based on a specified drainage coefficient/drainage intensity. The drainage coefficient provides a specified amount of water removal per day from agricultural lands. A study by Kalita et al. (2007) found that many existing drainage systems in Illinois are laid out in an irregular manner, based on the occurrence of low points in the field; this irregular drain pipe layout may not be adequate for future climatic conditions which may lead to the replacement or restoration of these drainage systems in the future. Future climatic patterns may affect the potential amount and timing of drainage water, and consequently crop production, thus it is essential to evaluate their impact on the design of subsurface drainage systems.

The main objective of this work was to develop a tool that can be used to simulate the performance of hypothetical drainage systems across the Midwest. This tool is easily accessible to a wide range of stakeholders, incorporates climate data from all across the region, and includes project climate data for simulating drainage system performance in the middle and at the end of the $21^{\text {st }}$ century.

Several researchers have simulated regional drainage performance. Thorp et al. (2008) used the RZWQM-DSSAT hybrid model with 25 years of historical climate data from each of 48 sites to simulate the performance of DWM across the Midwest. They used soil parameters that were calibrated for one site in Iowa, and drainage depth and spacing of 145 $\mathrm{cm}$ (4.75 feet) and $2740 \mathrm{~cm}$ (90 feet), respectively, at all 48 sites. Youssef et al. (2018) used DRAINMOD and DRAINMOD_NII to simulate DWM performance at the same 48 sites, using the same climate, soil and drainage system data. The interface presented here can be used for similar analyses of DWM in the Midwest, at a county level. It contains historical and projected climate data from 857 locations (one in each county in the Midwest), data from 23 soil series, and allows for user-specified drainage system depth and spacing.

The interface and the database were originally developed to assess the potential county-level impacts of climate change on subsurface drainage design in Illinois for the near future (2040-2069) and the far future (2070-2099) using projected climatological data from general circulation models (GCMs). The interface, developed in Microsoft Excel (Excel 2016) using Visual Basic for Applications (VBA), links climate data, heat indices and functionality such as crop management and economic analysis with DRAINMOD, a fieldscale deterministic hydrology model that simulates a soilwater regime of surface and subsurface drainage systems. The model predicts surface runoff, infiltration, evapotranspiration (ET), soil water content, and seepage from subsurface drained landscapes (Kale, 2011). The drainage-climate interface, integrated with DRAINMOD, was developed with the aim to optimize agricultural production under climate change. The developed interface facilitates the simulation of the performance of drainage systems based on site parameters, soil properties, and weather data. A combination of depth and spacing of drainage tiles that maximize overall crop yield under projected climate stress is considered optimal for purposes of this study. The potential impact of future climatic variables on the hydrology of the region was simulated using climatic scenarios from GCMs: CCSM4 and MIROC5. The future climatic data were obtained by using downscaled projections of these GCMs under the (representative concentration pathway) RCP8.5 scenario. Each RCP defines a specific emissions trajectory and subsequent radiative forcing. This study considers the RCP8.5 scenario as it is the worst-case scenario with the highest GHG emissions. The predicted future climatic variables (temperature and precipitation) were input to DRAINMOD to simulate subsurface drainage for Illinois. DRAINMOD simulations were used to determine the depth and spacing of tile drains that maximize crop yield for corn and soybean during the mid and late $21^{\text {st }}$ century.

Although developed mainly for Illinois, the interface can be used for other Midwestern states with subsurface drainage systems. It is suitable for county level simulations, that is for simulating drainage system performance in a specified county with a specified soil type. It is not suitable for sitespecific simulations; such simulations would require detailed information about surface conditions, field slope, field effective hydraulic conductivity, among others, and would likely require that DRAINMOD be calibrated using site-specific measurements. However, the interface provides for the extraction of county level weather data (precipitation, temperature, monthly PET factors, and monthly heat indices) that can be used for site-specific simulations.

\section{Climate Projections}

Climate change projections have been widely used for the assessment of the potential impacts of climate change on natural processes and human activity. These projections of climate are inferred from simulations obtained from general circulation models. This study focuses on the state of Illinois in the Midwest United States, for which the Great Lakes are a topographic influence and utilizes the statistical downscaling method for climate projections from GCMs to more accurately approximate the local environment (Winkler et al., 2011) This study utilizes two GCMs: CCSM4 and MIROC5, selected for being robust and well-established based on the overall recommendation of climate scientists. These GCMs have been used for several studies of regional climate change with acceptable performance for the Midwest United States (Knutti et al., 2013; Wuebbles and Hayhoe, 2004). The outputs from these models meet the timeframe as well as output format required for this study and were obtained from the World Climate Research CMIP5 multi-model dataset (Reclamation, 2013). The GCMs used in this study have been outlined in table 1 . 
Table 1. GCM outputs used in this study from the CMIP5 multi-model dataset.

\begin{tabular}{|c|c|c|c|}
\hline $\begin{array}{c}\text { GCM, } \\
\text { Vintage }\end{array}$ & Description & Institution & $\begin{array}{l}\text { Resolution } \\
(\text { Lat } \times \text { Lon })\end{array}$ \\
\hline CCSM4 & $\begin{array}{c}\text { Community } \\
\text { Climate } \\
\text { System Model }\end{array}$ & $\begin{array}{c}\text { National } \\
\text { Center for } \\
\text { Atmospheric } \\
\text { Research } \\
\text { (NCAR), USA }\end{array}$ & $0.9375^{\circ} \times 1.25^{\circ}$ \\
\hline MIROC5 & $\begin{array}{c}\text { Model for } \\
\text { Interdisciplinary } \\
\text { Research } \\
\text { On Climate }\end{array}$ & $\begin{array}{c}\text { Atmosphere and } \\
\text { Ocean Research } \\
\text { Institute, } \\
\text { University of } \\
\text { Tokyo, Japan }\end{array}$ & $1.4063^{\circ} \times 1.4063^{\circ}$ \\
\hline
\end{tabular}

According to Yokohata et al. (2011), a high similarity between GCMs would bias the results as the omission and parameterization of processes, numerical approximations, and simplifications by each GCM would be alike. Knutti et al. (2013) produced the climate model genealogy to compare models' similarity; models that are in the same branch of the genealogy have similarities in terms of model simulations. From the ensemble of models in the CMIP5, CCSM4 and MIROC5 were found to not be closely related by the Climate Model Intercomparison Project (CMIP5). Thus, these two GCMs were selected (due to their independence) to represent varying future conditions as well as different biases in climatology and the seasonal cycle. It is essential that an assessment of the potential impacts of climate change be informed by a proper understanding of the region's climate and represent the wide range of inherent uncertainties in future projections.

Downscaled CMIP5 climate projection data with a spatial resolution of $1 / 8^{\circ} \times 1 / 8^{\circ}$ were obtained from an archive containing fine spatial resolution climate projections. The archive dataset is based on global climate projections from the World Climate Research Programme's (WRCP's) CMIP5 multi-model dataset referenced in IPCC's Fifth Assessment Report. The dataset is hosted by multiple federations, universities, and NGOs including the Bureau of Reclamation, Climate Analytics Group, Climate Central, U.S. Army Corps of Engineers, and USGS amongst others; the archive is available as 'Downscaled CMIP3 and CMIP5 Climate and Hydrology Projections' (Reclamation, 2013). Bias correction was an implicit part of the statistical downscaling technique; the archive data were available as downscaled using the Bias Correction Constructed Analogs (BCCA) method. The BCCA method developed by Maurer and Hildago (2008) performs a lumped bias correction based on the month-specific probability distribution of daily data. The Constructed Analog downscaling method is based on the linear regression of historically observed weather that is analogous to future bias corrected GCM projection. The analogy is based on the representation of spatial patterns and intensity of climatic variables such as temperature and precipitation (Ahmed et al., 2013).

A database of downscaled GCM data was created for the entire Midwest region. The data range from the period 19802010 and 2040-2099. This study used the baseline period from 1980-2010 to determine if the climate model output were reasonable in comparison with historical observations. Projected data from 2040-2099 were used as input for the drainage-climate interface developed by this study to perform simulations that assess the potential impacts of climate change on the drainage systems in Illinois. The performance of CCSM4 and MIROC5 were analyzed in terms of the downscaled climatological variables: temperature and precipitation by comparing the resemblance between modelsimulated and observed meteorological patterns. Taylor diagrams (Taylor, 2001) were used to make a comparison between the observed and simulated temperature for each GCM, while precipitation was evaluated using the double mass curve method and monthly climate normals. The observed data for the baseline period from 1980 to 2010 were obtained from the National Climatic Data Center (NCDC). To analyze the accuracy of each GCM in reproducing climatic variables, the GCM data were compared to observed data from meteorological stations in Illinois. This article presents GCM performance analysis for Adams and Champaign counties in Illinois and focuses on these two counties as case studies of the drainage-climate interface.

Taylor diagrams provide "a concise statistical summary of how well patterns match each other in terms of their correlation, their root-mean-square difference and the ratio of their variances" (Taylor, 2001). Taylor diagrams plotted in figure 1 for maximum and minimum temperature for Adams and Champaign counties in Illinois show that MIROC5 and CCSM4 have similar RMSD (indicated by the green contours) and standard deviation while MIROC5 has a higher correlation (R) as shown by the position of the GCM point on the diagram. The values in bold shown in table 2 symbolize the more accurate statistical value for the three parameters $(\sigma, \mathrm{RMSD}$, and R). The Taylor diagrams show that MIROC 5 conformed better to observed temperature as compared to CCSM4.

Double mass curves have been commonly used to evaluate the temporal trend of hydro-meteorological data for long records. The technique is used for trend analysis because of its high transferability and low data requirement (Gao et al., 2017). Double mass curves were used to check the consistency of precipitation data simulated by CCSM4 and MIROC5 with observed data. Linear trends for a station show that the record at that station is consistent. The difference in the slope of the points in comparison with the one to one (linear) trendline indicates the degree of change in the relationship between observed and simulated precipitation (Searcy and Hardison, 1960). The plots (figs. 2 and 3) show that while the trend is not perfectly linear, it is approximately linear. The double mass curves for both GCMs indicate that the records are consistent although the points scatter slightly. For Adams and Champaign Counties, the double mass curve is marginally below the linear reference line, demonstrating that the GCMs slightly underestimated precipitation. The double mass curve analysis concluded that both CCSM4 and MIROC5 have consistent precipitation records suitable for this study.

A climate model's performance in reproducing historic climate is a representation of the reliability of the model's simulations (Miao et al., 2014; Nasrollahi et al., 2015). This study computes simulated climate normals for the period from 1980 to 2010 to assess the performance of the GCMs 


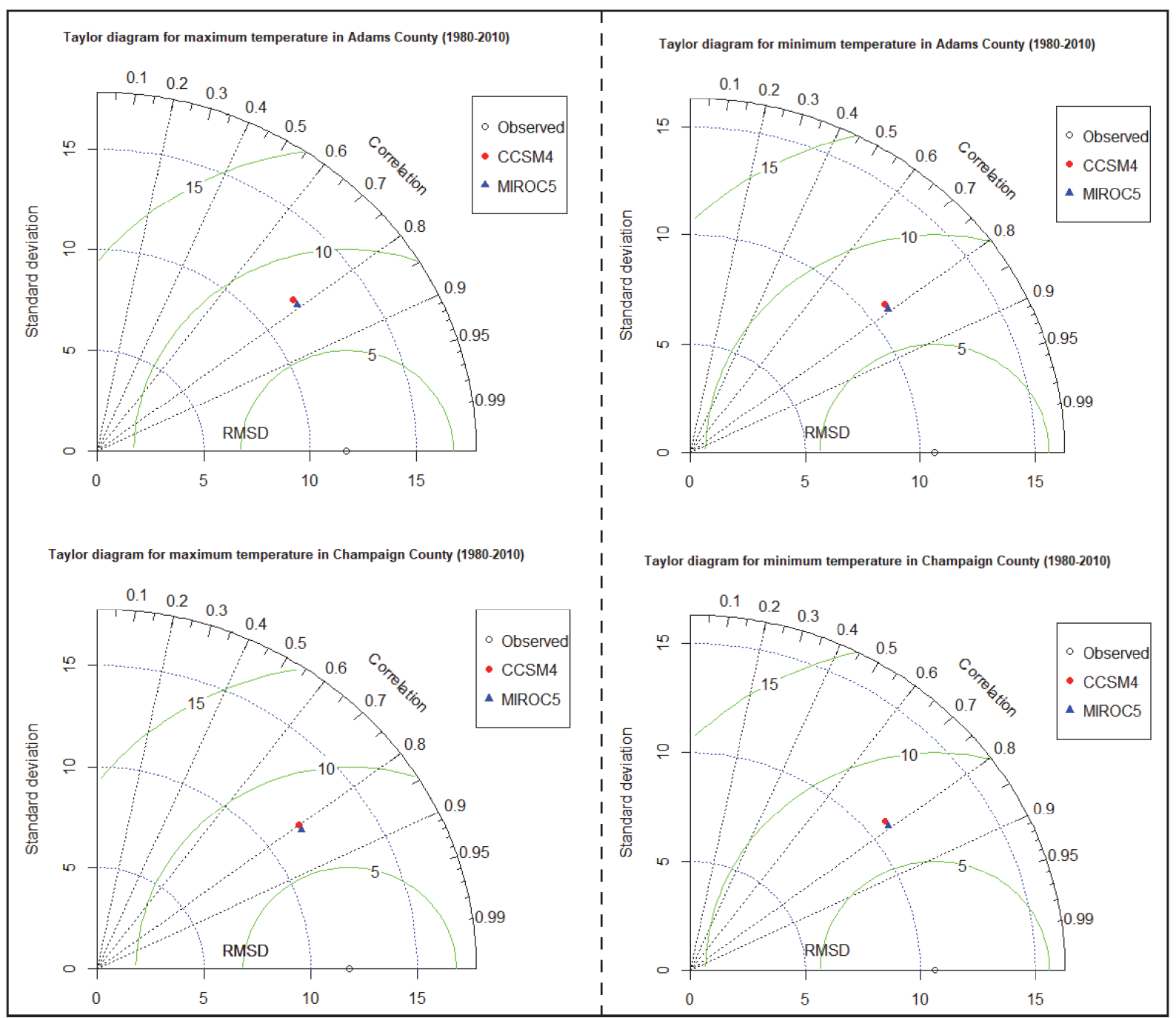

Figure 1. Taylor diagram for temperature $\left({ }^{\circ} \mathrm{C}\right)$ in Adams and Champaign Counties showing the correlation coefficient, root mean square difference (RMSD), and standard deviation.

in simulating precipitation by comparing it against actual climate normals (figs. 4 and 5). Climate normals are consecutive 30-year averages of climatological variables. Climatologists use three-decadal averages of precipitation to form a reference against which current conditions can be assessed. Multidecadal variability in the climate system causes a disparity in the climate normals from one 30-year period to another. According to the World Meteorological Organization (WMO), average precipitation over a 30 -year period are sufficient to adequately characterize the rainfall pattern at a station and its surroundings. Climate normals are used to evaluate anomalies in precipitation trends and can also be used as predictors of future climatic conditions (Arguez and Vose, 2011).

Evaluation of CCSM4 and MIROC5 for the simulation of precipitation patterns by means of climate normals and double mass curve demonstrate that one model does not have a superior performance relative to the other model. Both models showed comparable performance in terms of precipitation. However, since temperature simulated by MIROC5 conformed better with observed temperature, MIROC5 was selected to create the climatological database for the drainage-climate model.

Table 2. Taylor diagram results for maximum and minimum temperature $\left({ }^{\circ} \mathrm{C}\right)$.

\begin{tabular}{|c|c|c|c|c|c|c|c|}
\hline \multirow[b]{3}{*}{ County } & \multirow{3}{*}{$\begin{array}{c}\text { Statistical } \\
\text { parameters }\end{array}$} & \multicolumn{6}{|c|}{ Temperature } \\
\hline & & \multicolumn{3}{|c|}{ Maximum } & \multicolumn{3}{|c|}{ Minimum } \\
\hline & & Observed & CCSM4 & MIROC5 & Observed & CCSM4 & MIROC5 \\
\hline \multirow{3}{*}{ Adams } & $\sigma$ & 11.719 & 11.866 & 11.854 & 10.638 & 10.874 & 10.856 \\
\hline & RMSD & & 7.937 & 7.605 & & 7.171 & 6.920 \\
\hline & $\mathrm{R}$ & & 0.775 & 0.792 & & 0.779 & 0.793 \\
\hline \multirow{3}{*}{ Champaign } & $\sigma$ & 11.814 & 11.839 & 11.764 & 10.382 & 10.469 & 10.343 \\
\hline & RMSD & & 7.511 & 7.215 & & 6.898 & 6.570 \\
\hline & $\mathrm{R}$ & & 0.799 & 0.813 & & 0.782 & 0.799 \\
\hline
\end{tabular}




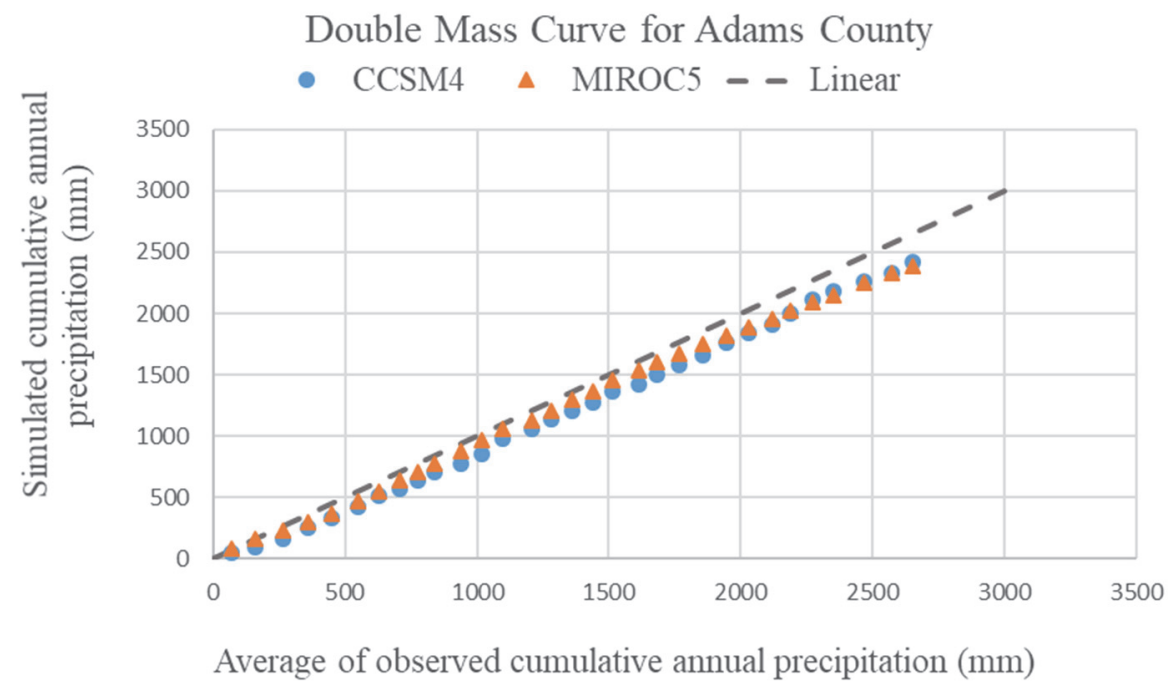

Figure 2. Double mass curve for simulated and observed precipitation in Adams County.

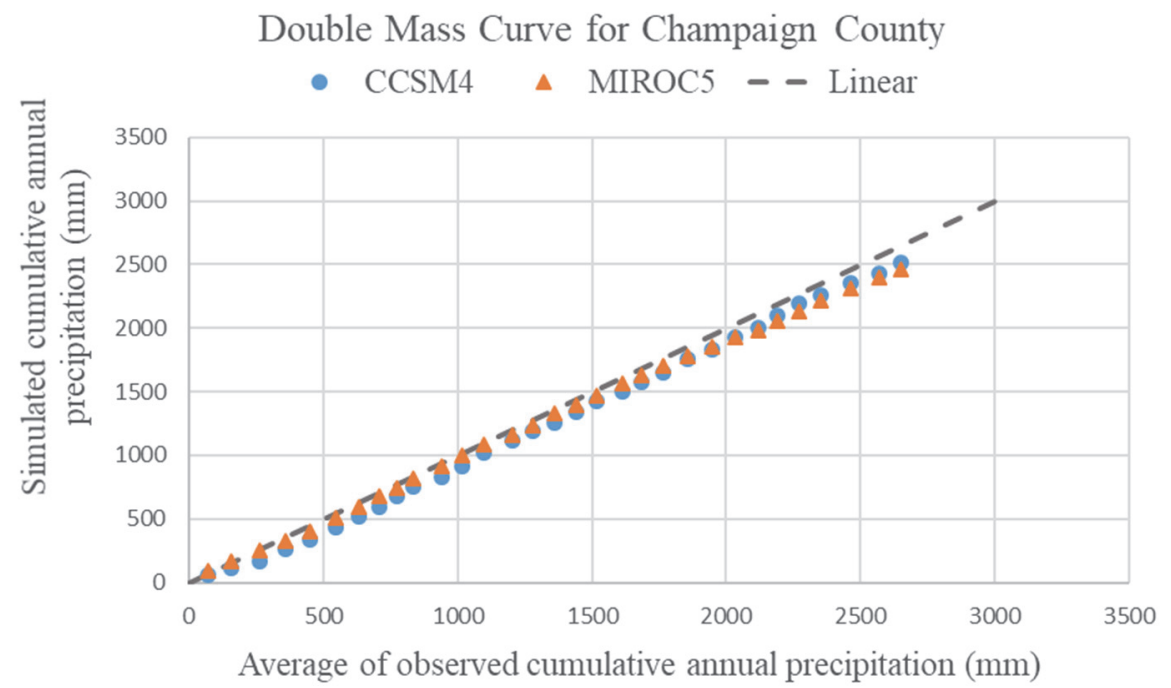

Figure 3. Double mass curve for simulated and observed precipitation in Champaign County.

The MIROC5 climate model was selected in this instance, for the reasons given above. However, new models are continuously being developed, and existing models are continually being refined. It is possible that another model might be more suitable if different selection criteria are used, or due to improvements in existing models. Therefore, the drainage simulation interface was just loosely coupled to the climate database, making it possible to change the climate model without having to change the interface. DRAINMOD includes a weather utility that can be used, as described below, to convert daily precipitation and temperature data into suitable formats that can be linked to the interface.

\section{DRAINAGE-Climate INTERFACE}

The interface was developed to connect climate and soil data from across the Midwest, with hypothetical drainage systems in which drainage depth and spacing can be varied. The interface is essentially a DRAINMOD pre- and post- processor, creating input files, running the model, and storing the output files. The database contains both actual and simulated temperature and precipitation, and soil data for the 102 counties in Illinois, as well as the other states in the Midwest U.S. from 1980 to 2010 and 2040 to 2099 . The interface allows the user to select a period for simulation: (1) 1980 to 2010, (2) 2040 to 2069 and (3) 2070 to 2099 as shown in figure 6. For the historic period from 1980 to 2010 the user has the option to compare model output produced by observational data with the output produced using simulated data from the MIROC5 GCM. Once the time period has been specified, a county and soil type can be selected from the drop-down menu (fig. 7).

Adjustable soil parameters comprise deep seepage and soil depth. The deep seepage parameters used by Thorp (2008) and Youssef (2018) were set as the default values in the interface. The user has the option of making the soil shallower or deeper, in which case the thickness of the soil layers are adjusted by the ratio of mean to specified profile depths. 
Average monthly precipitation (1980-2010) for Adams County

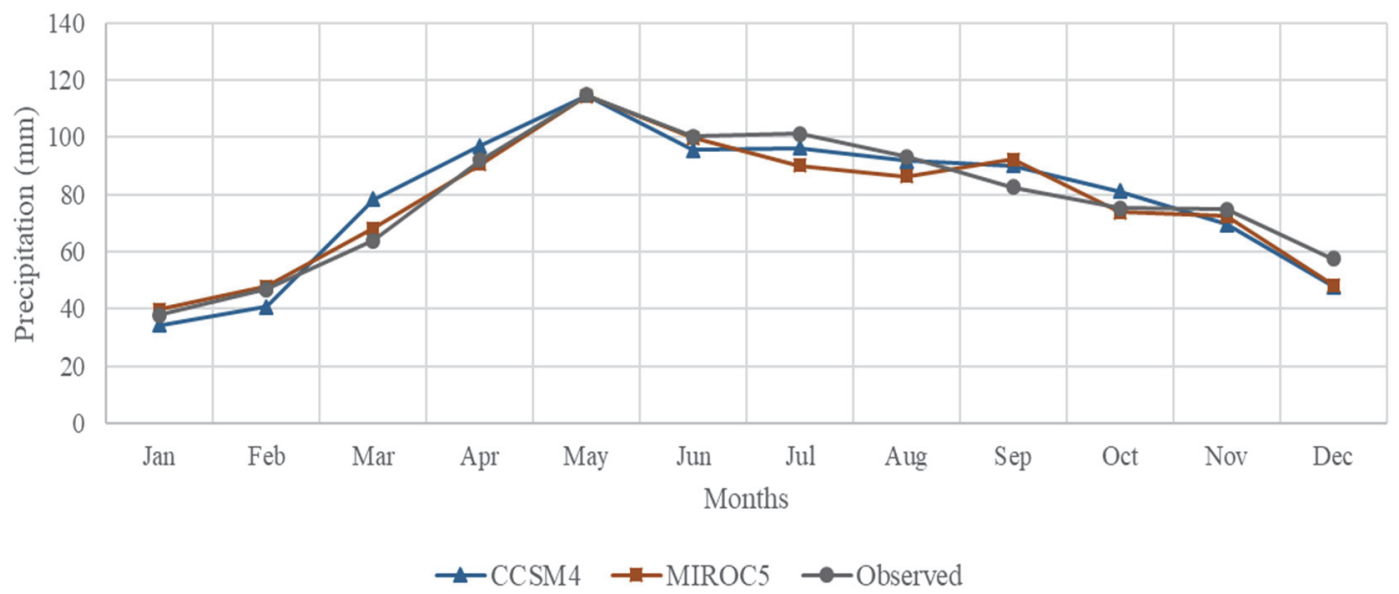

Figure 4. Climate normals (1980-2010) for Adams County.

The interface allows for county-level DRAINMOD simulation of conventional drainage or DWM from a hypothetical field with a specified soil. The field is flat with no lateral seepage and optional deep seepage. The interface can be used to simulate continuous corn or a corn/soybean rotation. DWM can be for implemented in the fallow season, the growing season, or in both seasons. The ranges and intervals for drain spacing and depth are specified by the user. Details of the various groups of input parameters are provided below.

\section{WEATHER INPUTS}

The DRAINMOD weather utility function was used to format historical temperature and precipitation data, and corresponding daily data from MIROC5, for model use. A start time and a duration are required to disaggregate daily precipitation data or use in DRAINMOD. Distributions for both parameters were obtained from 30 years of data for six stations across Illinois, and the $5^{\text {th }}, 50^{\text {th }}$, and $95^{\text {th }}$ percentile values for each parameter for each station were used to create
DRAINMOD input files. With all other parameters held constant, there were no differences in drain outflow or water table variation from combinations of the various percentile values for both parameters. Therefore, the default values in the DRAINMOD utility were used to disaggregate daily precipitation data. To create temperature files for DRAINMOD, the daily maximum and daily minimum air temperature $\left({ }^{\circ} \mathrm{C}\right)$ were input to the utility function. A climate file was created to associate rainfall, temperature, potential evapotranspiration (PET) and the heat index (I) for each county in Illinois for all time periods.

The climatological database was extended to cover not only Illinois but all the states in the Midwest U.S. with tile drainage (fig. 9). The extended climatological database contains temperature and precipitation data for each county of the following states: (1) Illinois, (2) Indiana, (3) Iowa, (4) Michigan, (5) Minnesota, (6) Missouri, (7) North Dakota, (8) Ohio, (9) South Dakota, and (10) Wisconsin. Actual and predicted temperature and precipitation data are available for the historic (1980 to 2010), near-future (2040 to 2069), and far-future (2070 to 2099) periods.

Average monthly precipitation (1980- 2010) for Champaign County

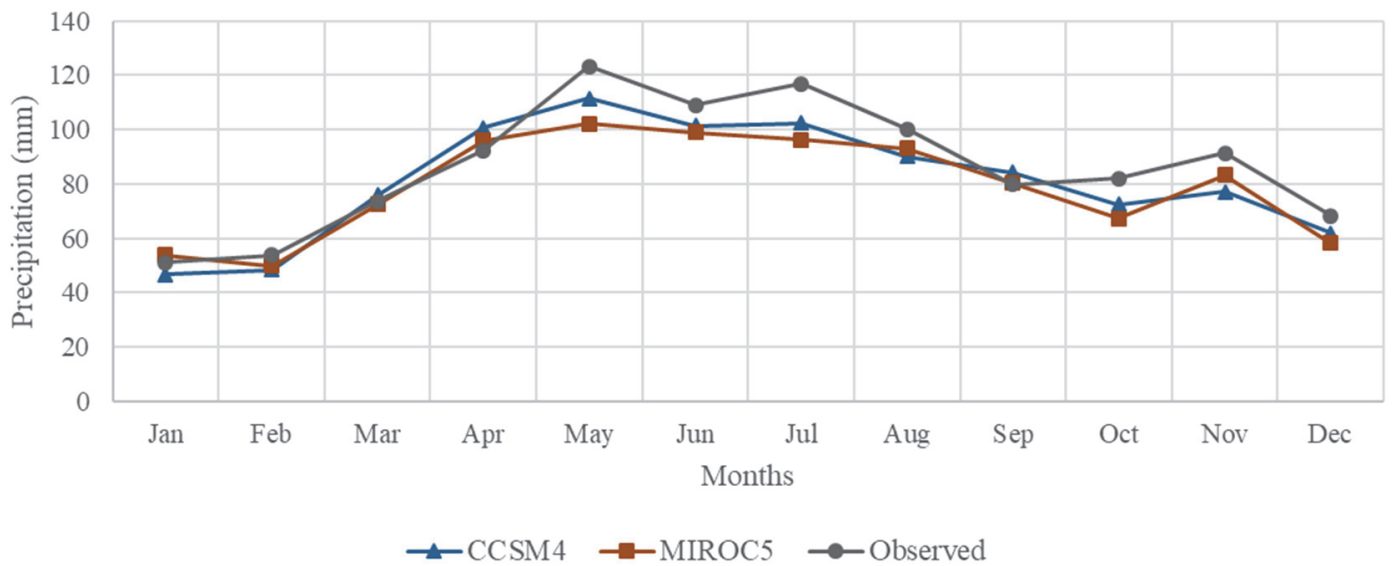

Figure 5. Climate normals (1980-2010) for Champaign County. 


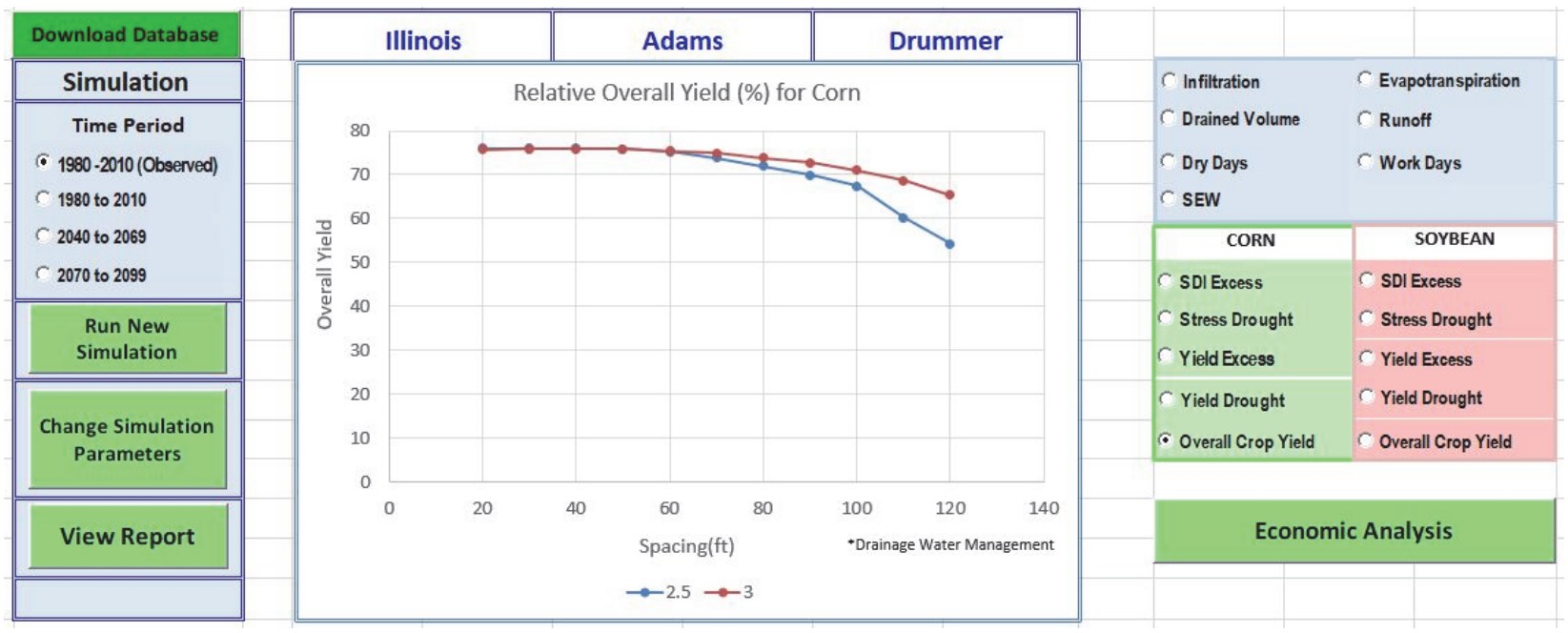

Figure 6. Main screen of interface.

\section{SOIL INPUTS}

DRAINMOD-formatted soil files have been developed for 23 major soil types in Illinois. Ashkum, Drummer, Flanagan, Ipava, Milford, Muscatine, Pella, Sable, and Virden soils, were developed for the Illinois NRCS by the USDA Soil Laboratory in Lincoln, Nebraska (Pitts, personal communication, 2004). Beaucoup, Bonnie, Darwin, Elliott, Herrick, Lawson, Selma, and Swygert were developed by Drablos et al. (1988). The others, comprising Bluford, Bryce, Cisne, Clarence, Gilford, and Houghton Muck were prepared by Christopher (2005), to ensure that there were at least two DRAINMOD formatted soils for each of the major drainage soil groups in the state. Each of the other hydric soils in Illinois were represented by one of these 23 soils, depending on drainage subgroup. There are but few DRAINMOD formatted soil files for hydric soils in the other states in the Midwest. They are represented by soil textural class average parameter values from the Rosetta model (Schaap et al., 2001)

\section{Crops ANd DRaINAGe Water MANAGEMENT}

Drainage water management and growing season management were included in the model. DWM maintains the water quality, reduces nutrient losses, and minimizes pollutant loading from drained fields by raising the outlet elevation of a drainage system above the drain invert, thereby
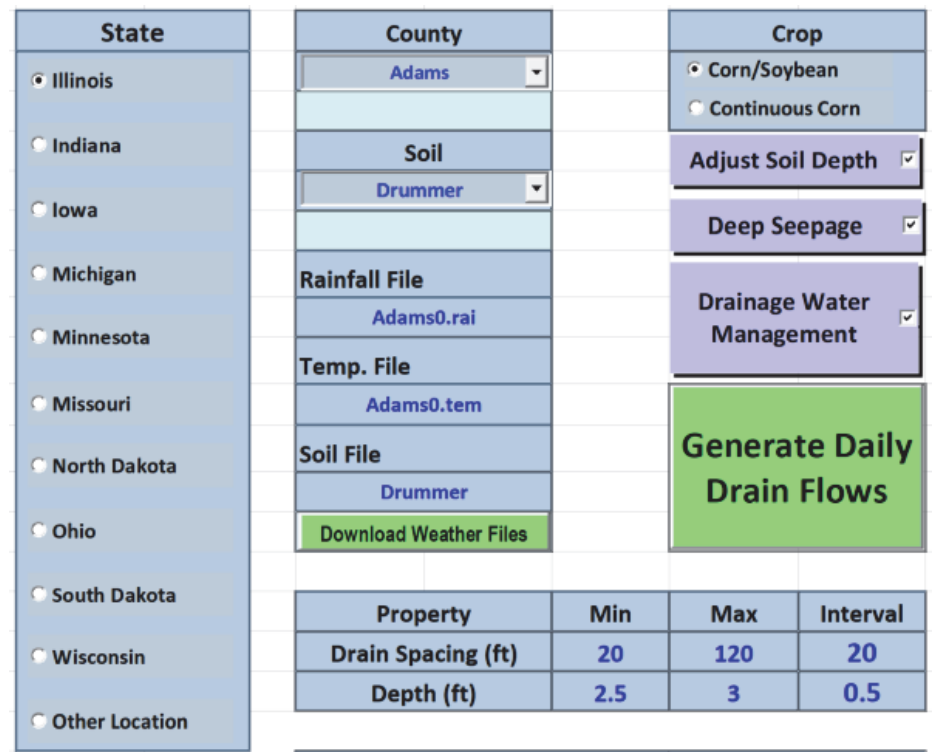

\begin{tabular}{|c|c|c|}
\hline \multicolumn{3}{|c|}{ Fallow Season } \\
\cline { 1 - 2 } Date to Raise Weir & Depth from \\
Month & Day & $\begin{array}{c}\text { Doil surface } \\
\text { to raised } \\
\text { outlet (in) }\end{array}$ \\
\cline { 1 - 2 } 11 & 1 & \\
\hline \multicolumn{2}{|c|}{ Date to Lower Weir } & \\
\hline Month & Day & \\
\hline 3 & 15 & 6 \\
\hline
\end{tabular}

\begin{tabular}{|c|c|c|c|}
\hline Property & Min & Max & Interval \\
\hline Drain Spacing (ft) & 20 & 120 & 20 \\
\hline Depth (ft) & 2.5 & 3 & 0.5 \\
\hline
\end{tabular}

\begin{tabular}{|c|c|c|}
\hline \multicolumn{3}{|c|}{ Growing Season Management } \\
\hline \multicolumn{3}{|c|}{ Growing Season } \\
\hline Date to Raise Weir & Depth from \\
Month & Day & $\begin{array}{c}\text { Deil surface } \\
\text { to raised } \\
\text { outlet (in) }\end{array}$ \\
\hline 6 & 1 & \\
\hline \multicolumn{2}{|c|}{} \\
\cline { 1 - 1 } Date to Lower Weir & Day & \\
\hline Month & 15 & 24 \\
\hline 8 & & \\
\hline
\end{tabular}

\begin{tabular}{|l|l|}
\hline Mean Soil Profile Depth (ft) & 152 \\
\hline Preferred Profile Depth (ft) & 152 \\
\hline
\end{tabular}

\begin{tabular}{|c|c|}
\hline Aquifer Piezometric head $(\mathrm{cm})$ & 200 \\
\hline Thickness of Restrict. Layer $(\mathrm{cm})$ & 200 \\
\hline Cond. Of Restrict. Layer $(\mathrm{cm} / \mathrm{hr})$ & 0.00006 \\
\hline
\end{tabular}

Figure 7. Screen for user specifications and drainage water management options. 
reducing drainage intensity and retaining water in the soil profile, at selected times of the year (Cooke et al., 2008). In DRAINMOD, the outlet elevation can be adjusted monthly. The drainage-climate interface provides the user the option to specify the date to raise and lower the control structure weir for both growing and fallow season (fig. 7). Additionally, the depth from the soil surface to the raised outlet (i.e., the weir elevation) can be adjusted in the interface. The adjustment dates and corresponding elevations are incorporated into the input file that is passed to DRAINMOD.

This study was developed to analyze crop yield for corn and soybean, common agricultural commodities in Illinois. The user has the option of choosing between corn and soybean rotation or continuous corn farming for the agricultural field.

\section{ECONOMIC ANALYSIS}

Many tools have been developed in the drainage-climate model to assist in the determination of the practicability of the drainage system. An economic analysis was included to determine the profitability of the drainage system for the user-specified range of depth and spacing. Alternatives are ranked in descending order by total profit in dollars per acre. The factors considered in the economic analysis include the interest rate on income, marginal tax rate, maximum corn and soybean yield (bu/acre), price for crops $(\$ / b u)$, lateral cost for tile drains $(\$ / \mathrm{ft})$, additional costs for the main and fittings such as maintenance costs and the life of the drainage system in years (fig. 8). The marginal tax rate is the amount of tax paid on an additional dollar of income. The marginal tax rate increases as the income rises. An estimate for corn and soybean yield (bu/acre) has been provided in the model based on USDA's National Agricultural Statistics for yield in Illinois for 2016 and 2017 (USDA-NASS, 2017). These default values can be altered by the user. Since crop prices for the future are not known, the user may conjecture the price for crops $(\$ / \mathrm{bu})$ and run model simulations. There are costs to the drainage system associated with the depth of the installed tile drains. Agricultural machinery is designed to install tile drains at a depth of up to 6 or $7 \mathrm{ft}$., defined as the critical depth in the interface. A depth of installation greater than the critical depth has an associated premium cost for the adjustment of the machine, or the temporary removal of the upper layers of the soil during installation. This additional cost can be included in the economic calculator as a 'depth premium'. The algorithm followed by the economic analysis calculator in the model is as follows:

1. Determine the length of tile required to cover an acre at the spacing modeled.

2. Determine the cost for drainage system installation per unit area, considering the length of tile required along with any extra costs associated with number of fittings, depth of installation, and the like.

3. Annual yield income per unit area, computed using the yield and commodity price for both corn and soybeans, and averaging them. This assumes a corn-soybean rotation, with each crop planted every other year.

4. Income before tax per unit area, computed by subtracting an amortized payment representing the cost of the installation of the drainage system over the expected life of the system (default value $=40$ years) from the annual yield income.

5. Total profit per unit area after tax, computed by applying the marginal tax rate to the income before tax.

An informed decision can be made for the placement of tile drains (depth and spacing) based on the crop yield and economic benefits determined by this study.

\section{Heat Index ANd Pet}

In DRAINMOD, daily or monthly potential evapotranspiration (PET) can be entered directly into the model, or the Thornthwaite method can be used to estimate PET. When the Thornthwaite method is used, monthly location-specific correction factors, relating Thornthwaite and energy balance estimated PET values, have to be specified.

In the Thornthwaite method (Palmer and Havens, 1958), PET for month $\mathrm{j}$ is given by:

$$
\begin{gathered}
\operatorname{PET}_{j}=1.6\left(\frac{10 T_{j}}{I}\right)^{C} \\
C=0.000000675 I^{3}-0.0000771 I^{2} \\
+0.01792 I+0.049239
\end{gathered}
$$

\begin{tabular}{|c|c|c|c|c|c|c|c|c|c|}
\hline \multirow{2}{*}{$\begin{array}{c}\text { State } \\
\text { Illinois } \\
\end{array}$} & \multirow{2}{*}{$\begin{array}{l}\text { County } \\
\text { Champaign }\end{array}$} & \multirow{2}{*}{$\begin{array}{l}\text { Soil type } \\
\text { Drummer }\end{array}$} & \multicolumn{7}{|c|}{ Economic Analysis } \\
\hline & & & Depth(ft) & Spacing(ft) & Tile Required(ft/ac & Cost for tile(\$/ac) & Yield Income (\$/ac) & Total Profit(\$/ac) & Alternatives ranked \\
\hline \multicolumn{2}{|c|}{ Interest Rate (\%) } & 12 & 2.50 & 20.00 & 2178.000 & & & & \\
\hline \multicolumn{2}{|c|}{ Marginal Tax Rate (\%) } & 10 & 2.50 & 30.00 & 1452.000 & 1966.640 & 10446.069 & 8479.429 & 22 \\
\hline \multicolumn{2}{|c|}{ Life of Drainage System (Years) } & 40 & 2.50 & 40.00 & 1089.000 & 1487.480 & $\begin{array}{l}10446.069 \\
10446.069\end{array}$ & $\begin{array}{l}8958.589 \\
9246.085\end{array}$ & $\begin{array}{l}19 \\
16\end{array}$ \\
\hline \multirow{2}{*}{\multicolumn{2}{|c|}{$\begin{array}{l}\text { Maximum Corn Yield (bu/acre) } \\
\text { Price for Corn }(\$ / \mathrm{bu})\end{array}$}} & 188 & 2.50 & 60.00 & 726.000 & 1008.320 & 10446.069 & 9437.749 & 13 \\
\hline & & 4.37 & 2.50 & 70.00 & 622.286 & 871.417 & 10446.069 & 9574.652 & 10 \\
\hline \multirow{2}{*}{\multicolumn{2}{|c|}{$\begin{array}{l}\text { Maximum Soybean Yield (bu/acre) } \\
\text { Price for Soybean }(\$ / \mathrm{bu})\end{array}$}} & 58 & 2.50 & 80.00 & 544.500 & 768.740 & 10446.069 & 9677.329 & 7 \\
\hline & & 10.11 & 2.50 & 90.00 & 484.000 & 688.880 & 10446.069 & 9757.189 & 4 \\
\hline \multicolumn{2}{|c|}{ Depth Specifications: } & & 2.50 & 100.00 & 435.600 & 624.992 & 10446.069 & 9821.077 & 1 \\
\hline \multicolumn{2}{|c|}{ Critical depth $(6-7 \mathrm{ft})$} & 7 & 3.50 & 20.00 & 2178.000 & 2924.960 & 10446.069 & 7521.109 & 25 \\
\hline \multirow{2}{*}{\multicolumn{2}{|c|}{ Depth premium (\$/ft) }} & 0.15 & 3.50 & 30.00 & 1452.000 & 1966.640 & 10446.069 & 8479.429 & 22 \\
\hline & & & 3.50 & 40.00 & 1089.000 & 1487.480 & 10446.069 & 8958.589 & 19 \\
\hline \multicolumn{2}{|c|}{ Costs: } & & 3.50 & 50.00 & 871.200 & 1199.984 & 10446.069 & 9246.085 & 16 \\
\hline \multicolumn{2}{|c|}{ Lateral Cost $(\$ / \mathrm{ft})$} & 1.2 & 3.50 & 60.00 & 726.000 & 1008.320 & 10446.069 & 9437.749 & 13 \\
\hline \multirow{2}{*}{\multicolumn{2}{|c|}{$\begin{array}{l}\text { Added cost for main and fittings (\% } \\
\text { Additional costs }(\$ / \text { acre })\end{array}$}} & 10 & 3.50 & 70.00 & 622.286 & 871.417 & 10446.069 & 9574.652 & 10 \\
\hline & & 50 & 3.50 & 80.00 & 544.500 & 768.740 & 10446.069 & 9677.329 & 7 \\
\hline & & & 3.50 & 90.00 & 484.000 & 688.880 & 10446.069 & 9757.189 & 4 \\
\hline
\end{tabular}

Figure 8. Example economic analysis in the drainage-climate interface. 
where I is the annual heat index, and $T_{j}$ is the mean monthly temperature, expressed in Celsius,

I, the sum of the monthly heat indexes $i_{j}$, is calculated using the following equations (Palmer and Havens, 1958):

$$
\begin{gathered}
I=\sum_{i=1}^{12} i_{j} \\
i_{j}=\left(\frac{T_{j}}{5}\right)^{1.514}
\end{gathered}
$$

The two major factors influencing PET are the amount of energy received from the sun (which accounts for about $80 \%$ of the variation in PET) and the wind. These factors are reflected by the mean diurnal temperature range $(\Delta)$ which correlates the effects of humidity and solar radiation on evapotranspiration (ET). Although climatic factors explain much of the variation in ET, vegetation cover also influences ET. The study by Sanford and Selnick (2012) provides two methods for computing PET correction factors. The first method applies the regression equation with parameter values for climate-only regression while the second method uses parameter values for climate-and-land cover-based regression. This study employs the climate-only regression equation to adjust the Thornthwaite PET estimates in the model. The regression equation (Sanford and Selnick, 2012) used to determine ET is as follows:

$$
\begin{gathered}
E T=P \Delta(\Gamma \Delta(\Gamma \Delta+\Pi)) \\
\Gamma=\left(T_{m}+T_{o}\right)^{m} /\left(\left(T_{m}+T_{o}\right)^{m}+a\right) \\
\Delta=\left(T_{x}-T_{n}\right)^{m} /\left(\left(T_{x}-T_{n}\right)^{m}+b\right) \\
\Pi=\left(P / P_{o}\right)^{n}
\end{gathered}
$$

where

$\mathrm{T}_{\mathrm{m}}=$ the mean annual daily temperature $\left({ }^{\circ} \mathrm{C}\right)$,

$\mathrm{T}_{\mathrm{x}}=$ the mean annual maximum daily temperature $\left({ }^{\circ} \mathrm{C}\right)$,

$\mathrm{T}_{\mathrm{n}}=$ the mean annual minimum daily temperature $\left({ }^{\circ} \mathrm{C}\right)$,

$\mathrm{P}=$ the mean annual precipitation $(\mathrm{cm})$,

$\Delta=$ the mean diurnal temperature range,

$\Gamma=$ the temperature variable for the equation,

$\Pi=$ the precipitation variable for the equation,

$\Lambda=$ a land cover variable, with a value of 1 for climate only regression.

The parameter values for climate-only regression are $\mathrm{T}_{\mathrm{O}}$ $=13.735, \mathrm{P}_{\mathrm{O}}=505.87, \mathrm{~m}=2.4721, \mathrm{n}=1.9044, \mathrm{a}=10,000$, and $b=18.262$. The PET correction factor is then calculated as the ratio of Thornthwaite PET to ET determined by climate data regression.

PET correction factors and heat index values were computed at the 25 intersection points of a grid of latitude and longitude superimposed over the Midwest United States (fig. 9). A PET correction factor table and twelve monthly heat index tables were created for each time period (1980 to
2010, 2040 to 2069 , and 2070 to 2099). The interface includes a two-dimensional linear interpolation routine that is used to determine PET and I values at the centroid of each county in the climatological database. These values are passed to DRAINMOD to determine PET in the respective counties.

Drainage intensity (DI) represents the steady state drainage rate $(\mathrm{cm} /$ day $)$ when the water table midway, between parallel drains is coincident with the surface. DI, determined by the Hooghoudt equation is dependent on factors such as hydraulic conductivity, radius of the drain, drain depth and drain spacing (Skaggs, 2017). Drain spacing plays an important role in determining the cost of a drainage system. A typical drainage system in the Midwest is designed with a drainage intensity of $0.9525 \mathrm{~cm}(3 / 8 \mathrm{in}$.): that is, the system is designed to remove $0.9525 \mathrm{~cm}(3 / 8 \mathrm{in}$.) of water in 24 hours when the water table is initially at the soil surface. This drainage intensity can be achieved with different combinations of depth and spacing. In Drummer Silty Clay Loam, for example, a $0.9525 \mathrm{~cm}$ (3/8 in.) drainage intensity can be achieved by installing corrugated plastic pipe drains $18.288 \mathrm{~m}(60 \mathrm{ft})$ apart at a depth of $0.762 \mathrm{~m}(2.5 \mathrm{ft})$, or by installing drains $30.48 \mathrm{~m}(100 \mathrm{ft})$ apart at a depth of $1.524 \mathrm{~m}$ (5 ft) (Cooke, 1998). The system with the more closely spaced laterals would be more expensive. In general, for a given depth, yield increases with decreased drain spacing up to a point because drainage intensity increases as drain spacing decreases. Beyond a certain point, further decreases in drain spacing would cause average yield values to drop as higher drainage intensities cause deficient soil water stresses (Skaggs and Murugaboopathi, 1994). The depth and spacing of drainage tiles that maximize overall crop yield are considered optimal.

In DRAINMOD, the Hooghoudt and Kirkham equations were used to predict drainage rate (Skaggs, 1981). These equations yield a good approximation of drainage flux even though drainage is not a steady state process. In a typical DRAINMOD simulation, the capacity of the drains is set high to not limit flow through them. In addition to drain outflow, DRAINMOD outputs include infiltration, evapotranspiration, drained volume, and surface runoff amongst others.

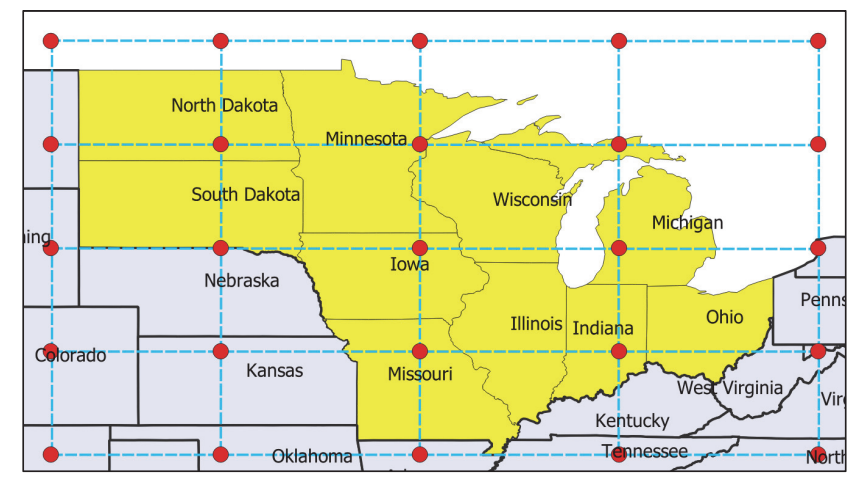

Figure 9. Grid point across Midwest U.S. at which PET and heat index values were determined. Drainage Intensity 


\section{EXAMPLE APPLICATION}

As a case study, the drainage-climate interface was run for hypothetical fields in Adams and Champaign counties in west-central and east-central Illinois, respectively. Model output was simulated using the dominant hydric soil in each county. The soil type was based on the highest proportionate extent of farmable soil (expressed as a percent) determined by the NRCS Soil Survey (USDA, 2017). DWM was also applied to Champaign County, and its effect examined. DWM settings are shown in figure 10. The dates to raise and lower the weir and the depth from soil surface to raised outlet can be adjusted by the user before performing simulations.

For each county, simulations were performed with (1) historical rainfall and temperature data for 1980-2010, and corresponding climate model data for (2) 1980-2010, (3) 2040-2069 (near future), and (4) 2070-2099 (far future). Drain spacing from 6 to $30.5 \mathrm{~m}$ (20 to $100 \mathrm{ft}$ ) at intervals of $3 \mathrm{~m} \mathrm{(10} \mathrm{ft)} \mathrm{and} \mathrm{drain} \mathrm{depths} \mathrm{of} 0.76$ and $1.4 \mathrm{~m}$ (2.5 and 4.5 $\mathrm{ft}$ ) were specified for the simulations. The complete set of

\begin{tabular}{|c|c|c|}
\hline \multicolumn{3}{|c|}{ Fallow Season } \\
\hline \multicolumn{2}{|c|}{ Date to Raise Weir } & \multirow{5}{*}{$\begin{array}{l}\text { Depth from } \\
\text { raised } \\
\text { outlet to } \\
\text { the soil } \\
\text { surface (in) }\end{array}$} \\
\hline Month & Day & \\
\hline 11 & 1 & \\
\hline \multicolumn{2}{|c|}{ Date to Lower Weir } & \\
\hline Month & Day & \\
\hline 3 & 15 & 6 \\
\hline
\end{tabular}

Figure 10. Drainage water management settings applied to the drainage-climate interface. results may be found in Adhikari (2018); the results are summarized in figures 11 to 17 , where the model output variable is plotted on the y-axis, and the drain spacing is on the $\mathrm{x}$ axis. The tile depths of $2.5 \mathrm{ft}$ (dashed line) and $4.5 \mathrm{ft}$ (solid line) are plotted for each drain spacing within the 20 to $100 \mathrm{ft}$ range. The drain spacing points are symbolized by dots on the plotted lines.

Overall, simulated yields for 1980-2010 produced with historical data and climate model data were similar for each depth and spacing combination. In figures 13 and 14 for Champaign County, yields obtained using the historical climate data is shown in blue, while yield obtained using climate model data for the same 1980-2010 period are shown in green. The similarities of corresponding curves are indicative that the climate model data were an adequate representation of observed data. This result was true for both corn and soybean yields in Champaign County. For Adams County (figs. 11 and 12), the yield obtained from observed and climate model data for 1980-2010 were not as similar as the yields in Champaign County. The difference may be indicative of microclimate effects in the more forested Adams County that are not represented in the climate model.

Crop yield trends are similar over a spacing from 20 to $100 \mathrm{ft}$ at an interval of $10 \mathrm{ft}$, with both corn and soybean yield seen to be decreasing as drain spacing increases. Corn yield in the near-future reduced to almost half of the present yield. The yield decline in the far future may be due to higher temperatures, consistent with previous studies (Melillo et al., 2014) that state that corn yields fail at high temperatures (above $95^{\circ} \mathrm{F}$ ). Potential future adaptations to climate change for corn yields would require an increased tolerance to

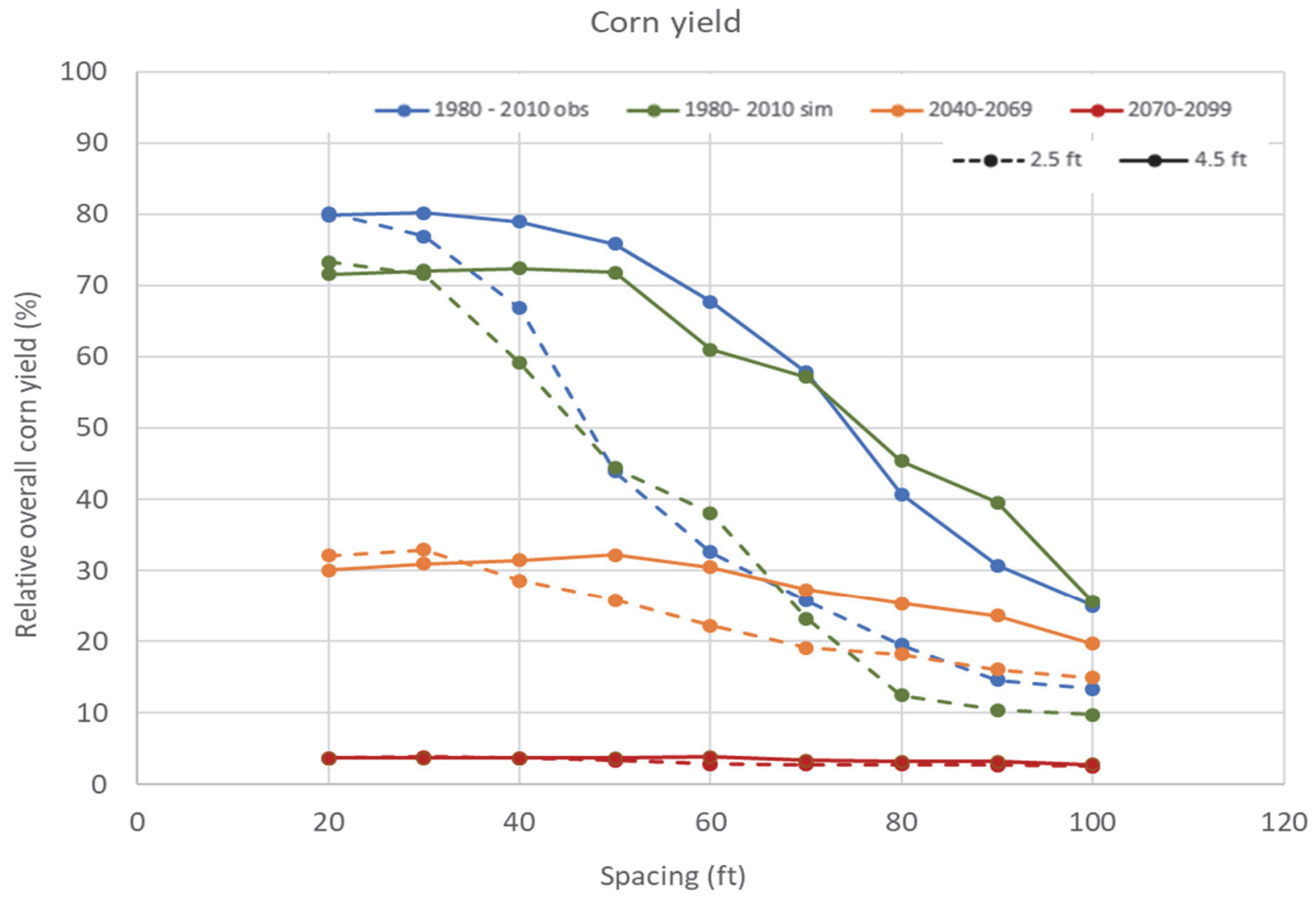

Figure 11. Corn yield for Adams County. 


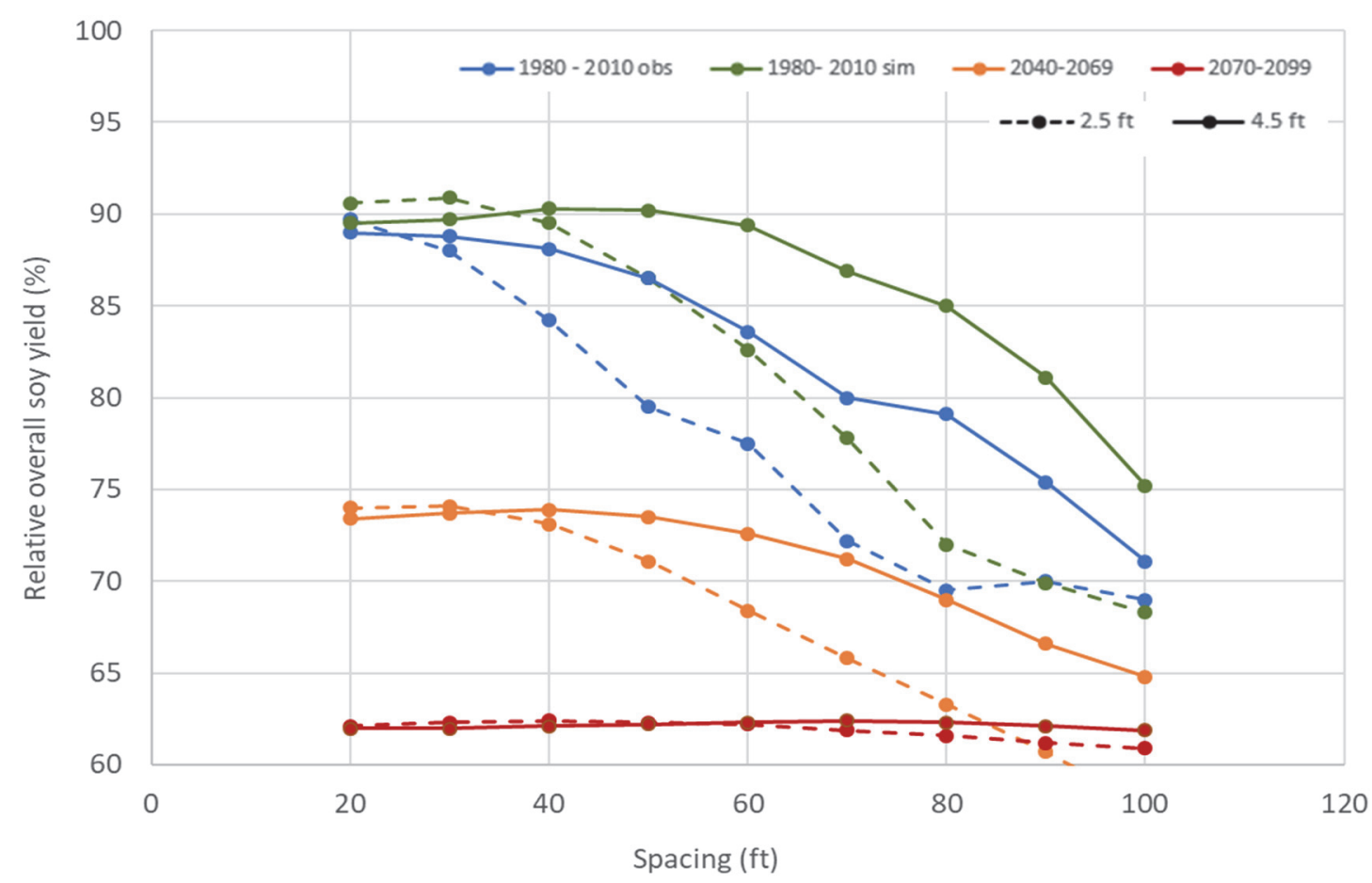

Figure 12. Soybean yield for Adams County.

higher temperatures or a change in the variety of crops grown. The yield for soybean was affected less than corn. Soybean yield showed a gradual decline over the years. Soybean benefits more than corn from $\mathrm{CO}_{2}$ fertilization (Southworth et al., 2000; UCS, 2009), which explains the slower rate of decrease.
Adams County was analyzed with Keomah silt loam (proportionate extent: $4.8 \%$ ), for which the representative soil is Herrick silt loam. Herrick consists of very deep, poorly drained soils formed in loess. Across the different time periods, the drained volume did not show a significant change; there was a slight decrease in the near-future which remained

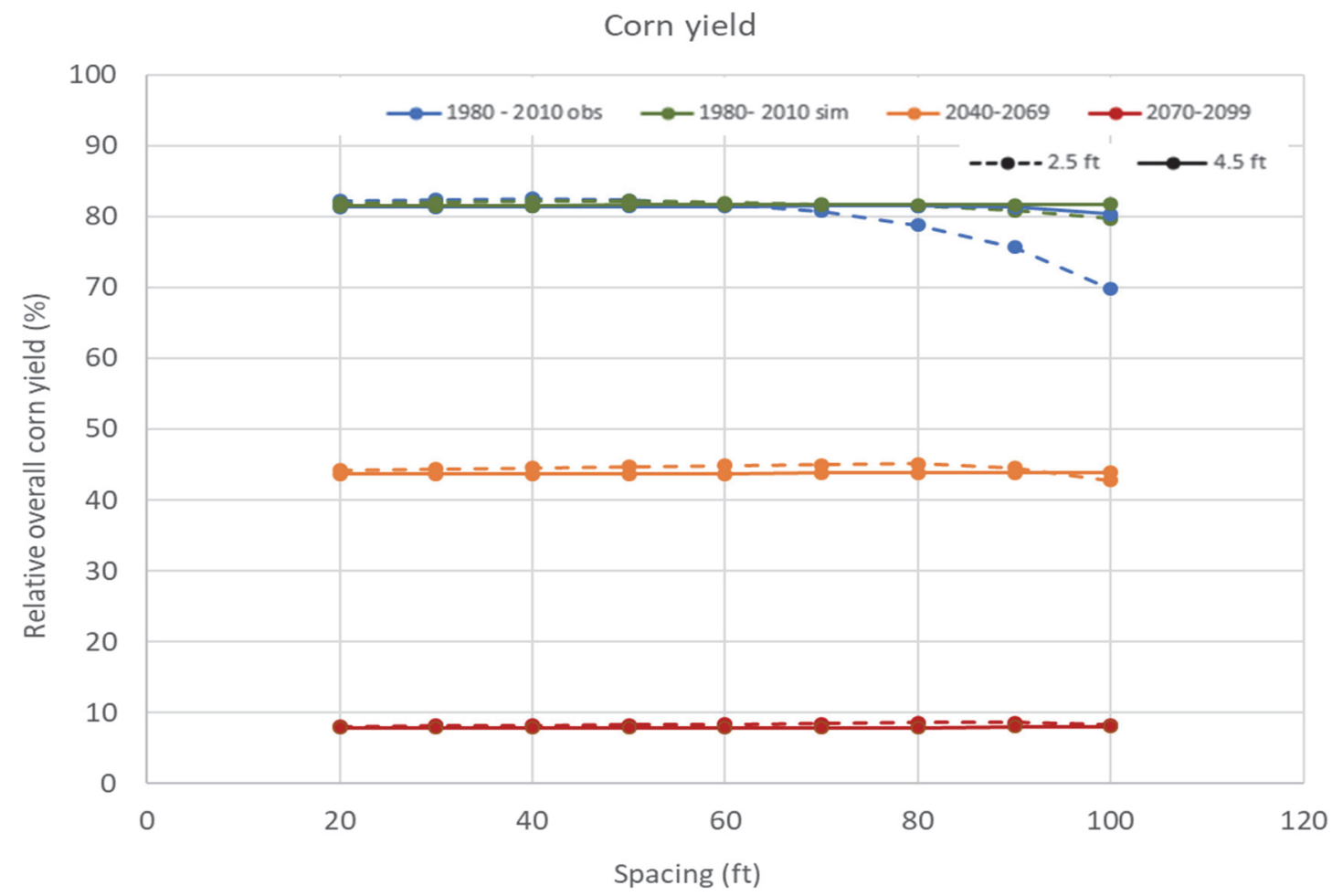

Figure 13. Corn yield for Champaign County. 
Soybean yield

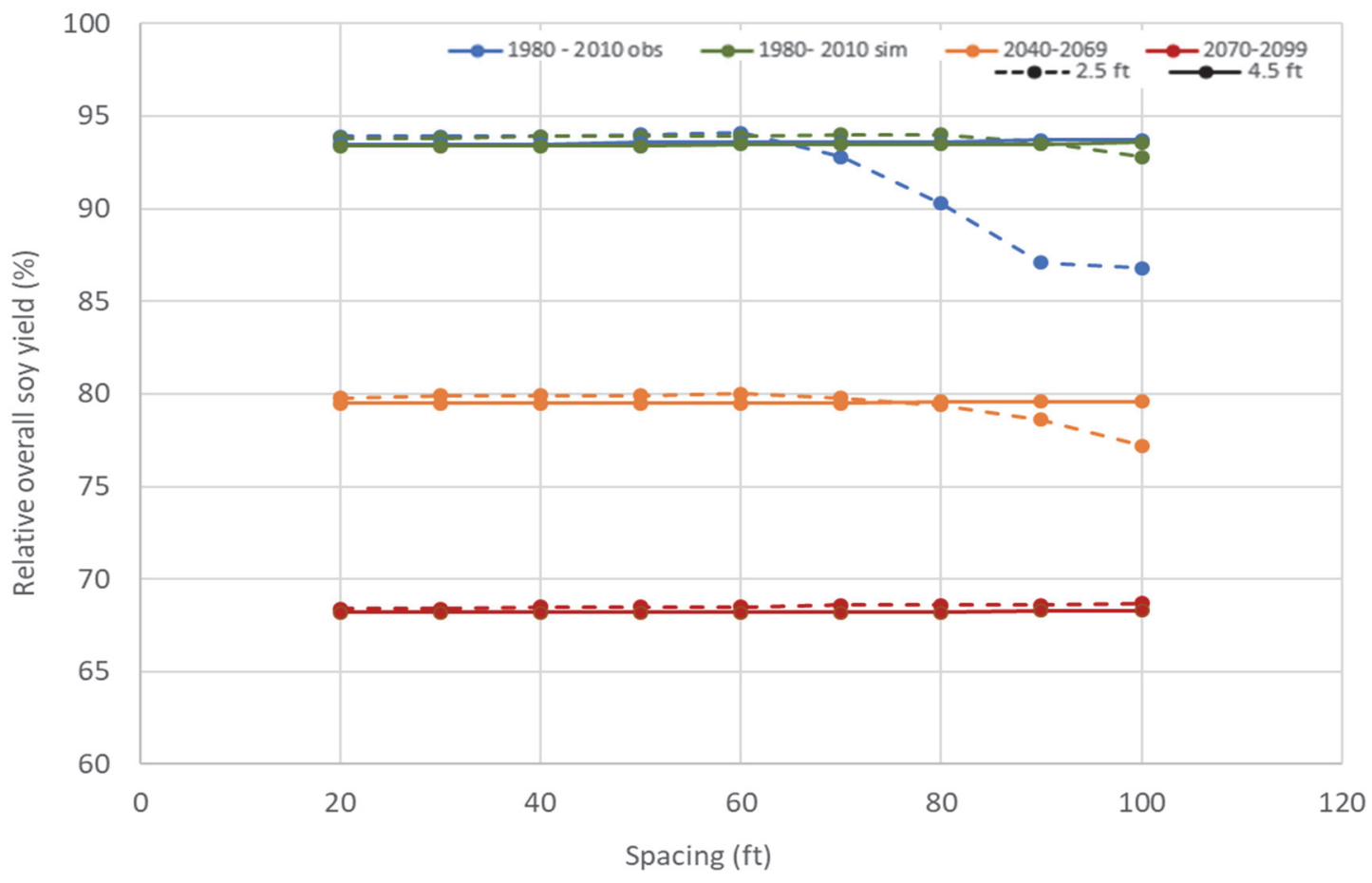

Figure 14. Soybean yield for Champaign County.

consistent for the far future. For Adams County, the optimal depth was found to be $4.5 \mathrm{ft}$. The depth of $4.5 \mathrm{ft}$ was deemed optimal as the yield (for corn and soybean) was consistently the highest at that depth across all spacings (figs. 11 and 12). The highest yield was produced at the optimal depth at a spacing between 20 to $60 \mathrm{ft}$ until 2069, and at an increased spacing of 40 to $80 \mathrm{ft}$ from 2070 until the end of the century.
For Champaign County subsurface drainage was simulated with Drummer silty clay loam (proportionate extent: $39.8 \%$ ). Champaign had an optimal depth of $2.5 \mathrm{ft}$, which correlated to the highest yield and lowest drained volume (figs. 13 and 14, respectively). A shallow tile depth was well suited for the soil types in this county. Optimal spacing for Champaign was between 20 to $60 \mathrm{ft}$ for the baseline period and 60 to $90 \mathrm{ft}$ for the future periods (figs. 13 and 14).

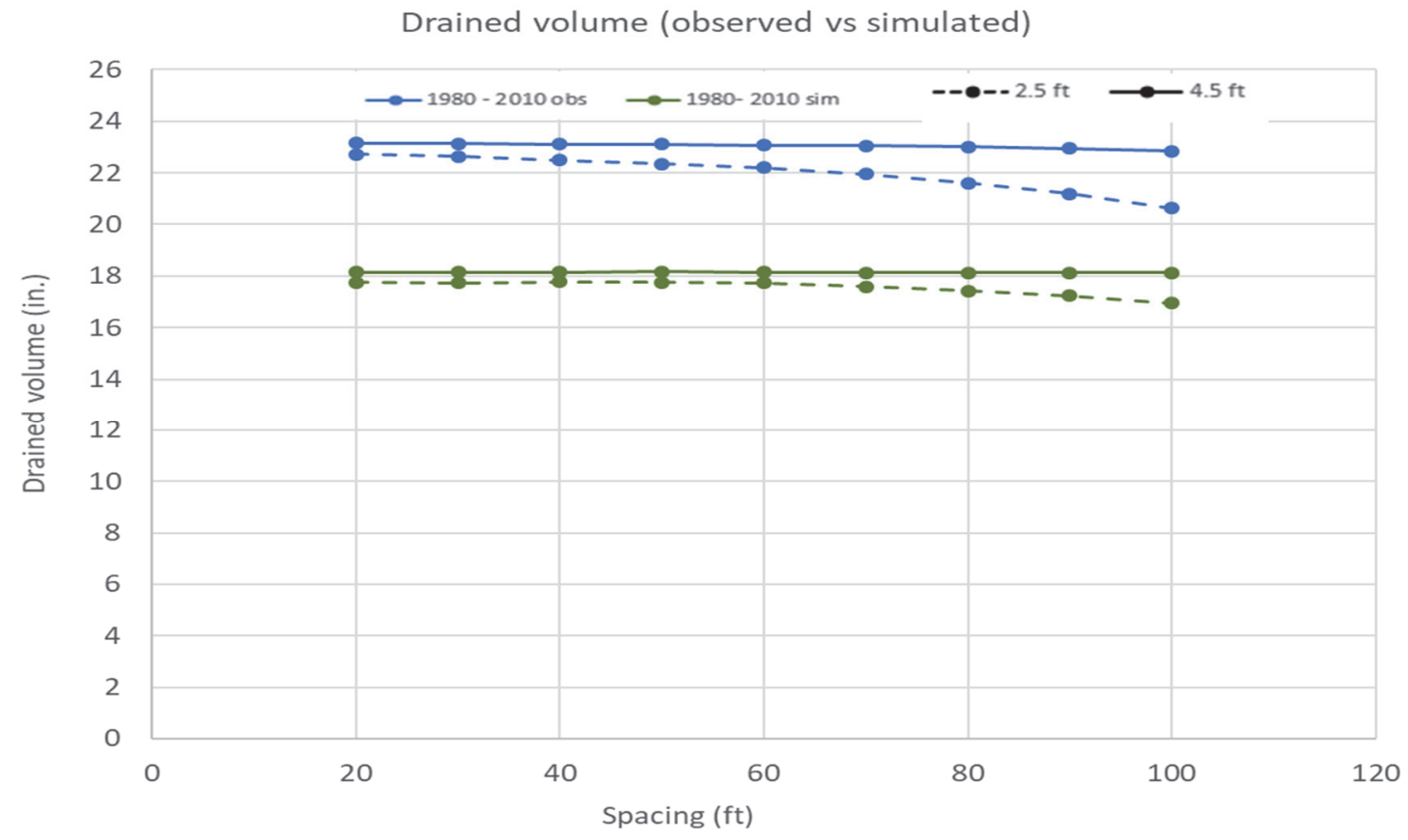

Figure 15. Observed versus simulated drained volume (in.) for Champaign County. 


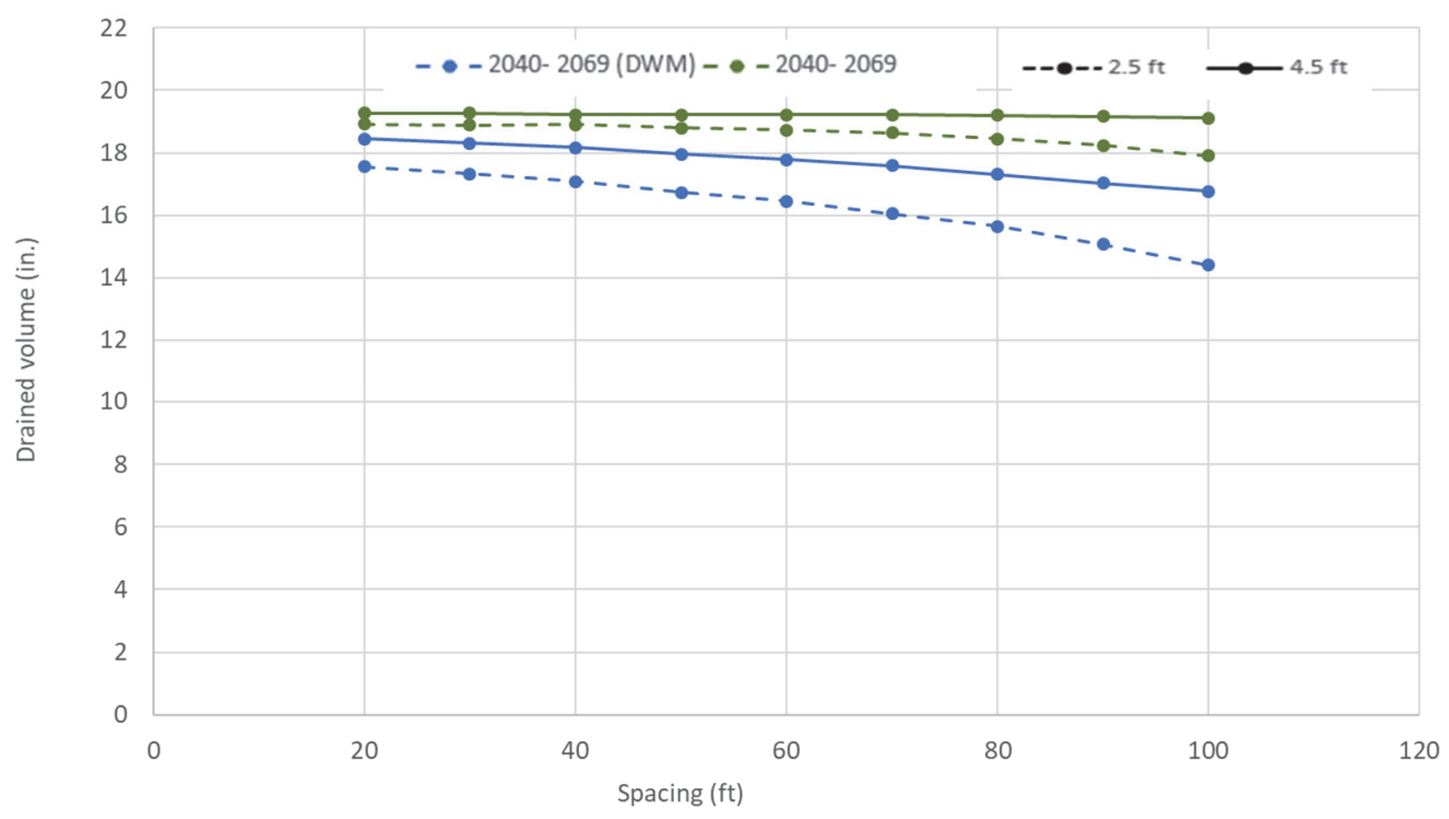

Figure 16. Drained volume (in.) with and without drainage water management for Champaign County for 2040-2069.

The differences in the optimal depth/spacing for the two counties is likely due to differences in weather as well as the hydraulic characteristics of the two soils used for simulation (fig. 18). Herrick has a layer with an extremely low conductivity between 38 and $89 \mathrm{~cm}$, whereas Drummer does not. The highest conductivity layer occurs at the bottom of the soil profile in Drummer and at the top of the profile in Herrick.

Results for Champaign County in figure 16 shows that the simulated drained volume for the baseline period (1980 to 2010) was lower than the actual drained volume obtained us- ing observed temperature and precipitation for the same period. The same trend was observed for Adams County. This indicates a moderate underestimation of the climatic variables simulated by MIROC5, possibly a consequence of the GCM underestimating observed precipitation (figs. 2 and 3). Differences may also be due to differences in temporal rainfall distribution patterns. Nonetheless, the trendlines for tile depth and spacing for which simulations were performed in the drainage-climate model show a similar pattern for drained volume obtained using observed versus simulated climatic variables for the baseline period.

Drained volume for 2070 - 2099 (with vs. without DWM)

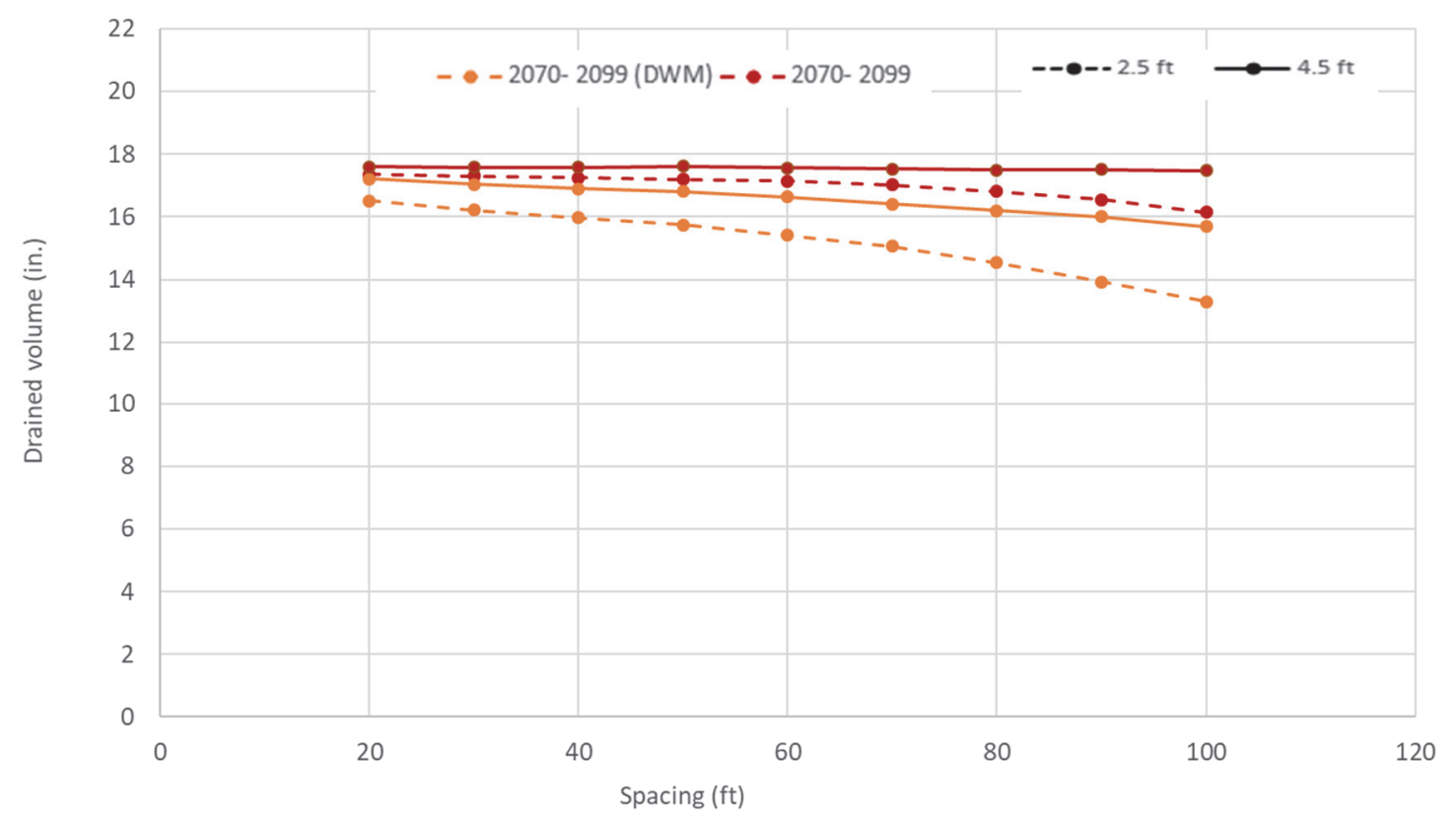

Figure 17. Drained volume (in.) with and without drainage water management for Champaign County for 2070-2099. 


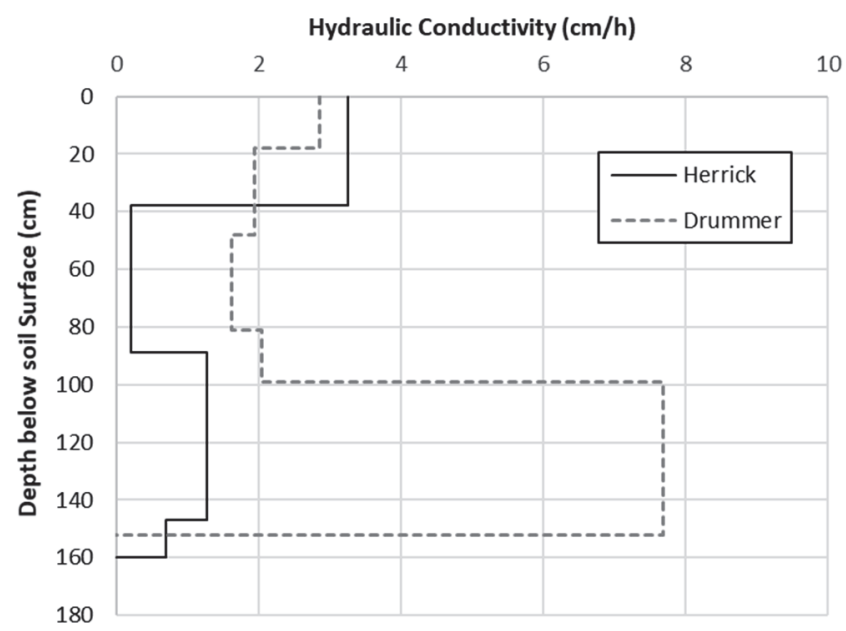

Figure 18. Relationship between saturated conductivity and depth in Herrick silt loam and Drummer silty clay loam.

MIROC5 under predicts rainfall in the crucial growing months of May through August, albeit to a different extent in both counties (figs. 4 and 5), resulting in the underestimation of drained volume for the baseline period. This under prediction introduces uncertainty into the climate model's prediction of rainfall during these months in the future, reducing the reliability of predicted drained volume and crop yields. In addition, the variability of anticipated precipitation in the future may cause the volume drained to deviate from model simulations. An approach to reducing the uncertainty in yield predictions would be to select a climate model based on weighted goodness-of-fit statistics, with higher weights during the growing period. Because of the loose coupling between the interface and the database, MIROC5 can be replaced in the database without necessitating changes to the interface.

DWM was incorporated for Champaign County for the future periods (2040 to 2069 and 2070 to 2099). DWM reduced drained volume with a minimal effect on crop yield. Applying DWM decreased the drained volume by an average of 2 in. for the near future, and 1.5 in. for the far future. A decrease in drained volume is desirable for future periods with higher temperatures and dry periods during which the soil needs to maintain moisture content for crop growth. The drainage-climate interface simulations predict that DWM will have a minor but positive influence on overall crop yield as shown on the complete set of results in Adhikari (2018). This yield result is consistent with current research on DWM (Skaggs et al., 2012). DWM options may be further analyzed by users of the interface, or weir raising and lowering dates adjusted to assess its impact on other output variables of the drainage-climate interface.

The optimization of subsurface drainage design is necessary as the drainage system is closely associated with crop production and can be used to maximize yield. Results from this study highlight the county-level variability of crop responses to changed environmental conditions. This analysis concludes that a hydrological simulation model, such as DRAINMOD, can be linked with a climate model to explicate the consequences of environmental effects on crop physiological processes under future scenarios of climate change. The accuracy of such analyses are dependent of the accuracy of both the climate and the hydrological models.

\section{SuMmary AND CONCLUSIONS}

This article presents the development of a drainage-climate interface that incorporates climatological data, crop drainage requirements and drainage theory into a procedure for characterizing drainage system response under different climate scenarios. The drainage-climate interface is suitable for assessing potential county-specific impacts of climate change on crop production, soil hydrology and subsequently on subsurface drainage design. Model simulations can be used to determine the tile depth and spacing that correlates to the minimum reduction in relative yield depending on the climate and soil type.

The climatological database, containing maximum air surface temperature, minimum air surface temperature, and daily precipitation, was created using projections from the MIROC5 GCM with datasets ranging from 1980 to 2010 and 2040 to 2099. The performance of the MIROC5 GCM in simulating climate variables was analyzed for temperature using the Taylor diagram, and for precipitation using the double mass curve. MIROC5 showed a consistent temporal trend of meteorological data and a good agreement between the empirical data and the model simulations. However, the climate model under predicted precipitation norms during the months of May through August, the main growing season in the Midwest. The climate model is loosely coupled to the interface, making it easy to change the model without necessitating changes to the interface.

In example applications of the drainage-climate interface for the baseline (1980 to 2010) and future (2040 to 2069 and 2070 to 2099) periods, there was an overall pattern of decreasing crop production under scenarios of climate change. The accuracy of such analyses are dependent on the accuracy of both the climate and the hydrological models. For Adams County, during the mid-century there was a significant decline in crop yield primarily due to intense heat during the main growth period.. The range in temperature during the period from 2070 to 2099 was unfavorable for the growth of crops since high temperatures for extended periods cause irreversible damage to plant function or development. Soybean yield was less affected with a progressive yet unalarming decline as soybean benefits from increased atmospheric $\mathrm{CO}_{2}$ concentrations promoting increased growth and tolerance to hot temperatures. Future periods required a decrease in drainage intensity with wider drain spacing to optimize crop yield. As shown by the model simulation results, incorporating DWM decreased the drained volume but did not significantly increase yield. Even though DWM does not have much of an effect on crop yield in the model, incorporating DWM could still be applied as an insurance factor against potential drought stresses since the drained volume with DWM is less compared to that without DWM. Water retained in the soil would aid agricultural growth during periods of extreme heat in the future. DWM can be used to reduce off-field water transport during stressed conditions. 
The depth and spacing requirements of drainage systems under climate stress need to be factored in the design of future drainage systems and restoration of existing networks.

The interface in intended to be used for county-level drainage simulations; it is not suitable for site-specific simulations. Such an application requires detailed information on soil, topography and agro-technical practices, and the use of observed data to calibrate DRAINMOD. However, the interface can be used to extract county-level weather data for use in site-specific simulations. The interface and the database are available on the Illinois Drainage Guide (http://www.wq.illinois.edu/DG/DrainageGuide.html) by selecting the "County Specific Simulations" option under the "Drainage Guidelines" heading (fig. 19). For agricultural practices in Illinois to sustain crop yield under future climatic conditions, this drainage-climate interface may be applied to the design of drainage systems. Further research may involve extending the representative soils for the Midwest, including climatic data from multiple GCMs, verifying the model's ability to simulate effects of DWM (on yield and drainage volume) using field data, or evaluating the impact of climate change on other output variables of the drainageclimate interface.

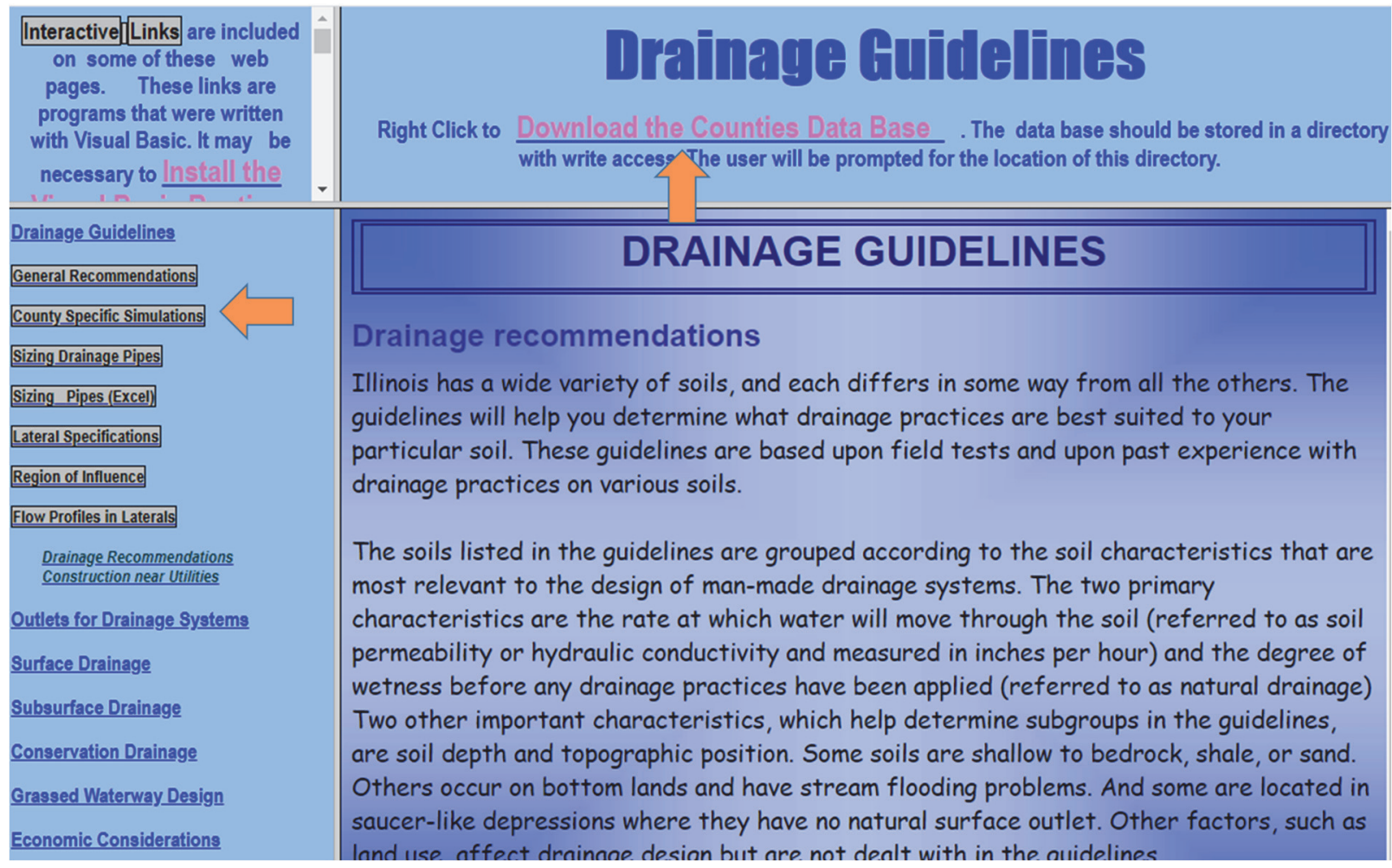

Figure 19. Location of the County Specific Simulation application and database on the main page of the Illinois Drainage Guide.

\section{ACKNOWLEDGEMENTS}

This research was funded in part by USDA NIFA Food Security Program grant award number 2016-68004-24769, USDA NIFA HATCH project ILLU-741-323, and the USDA - Natural Resources Conservation Service.

\section{REFERENCES}

Adhikari, N. (2018). Development of DRAINMOD-based VBA model for evaluating drainage system response. (Unpublished Master's thesis). University of Illinois at Urbana-Champaign. Retrieved from http://hdl.handle.net/2142/102441

Ahmed, K. F., Wang, G., Silander, J., Wilson, A. M., Allen, J. M., Horton, R., \& Anyah, R. (2013). Statistical downscaling and bias correction of climate model outputs for climate change impact assessment in the U.S. northeast. Global Planetary Change, 100, 320-332.

https://doi.org/10.1016/j.gloplacha.2012.11.003
Arguez, A., \& Vose, R. S. (2011). The definition of the standard WMO climate normal: The key to deriving alternative climate normals. Bull. American Meteorological Soc., 92(6), 699-704. https://doi.org/10.1175/2010bams2955.1

Christopher, K. I. (2005). A DRAINMOD-based decision support system (DSS) for drainage and water quality in Illinois. (Unpublished PhD thesis). University of Illinois at UrbanaChampaign. Retrieved from http://hdl.handle.net/2142/86060

Cooke, R. (1998). Water management. In Illinois agronomy handbook. University of Illinois at Urbana-Champaign. Retrieved from http://extension.cropsciences.illinois.edu/handbook/pdfs/chapter 11.pdf

Cooke, R. A., Sands, G. R., \& Brown, L. C. (2008). Drainage water management: A practice for reducing nitrate loads from subsurface drainage systems. Proc. Gulf Hypoxia and Local Water Quality Concerns Workshop - Final Report (pp. Ch. 2, 19-28). St. Joseph, MI: ASABE. 
Cooke, R., \& Verma, S. (2012). Performance of drainage water management systems in Illinois, United States. JSWC, 67(6), 453-464. https://doi.org/10.2489/jswc.67.6.453

Drablos, C. J. W., Konyha, K. D., Simmons, F. W., \& Hirschi, M. C. (1988). Estimating soil parameters used in drainmod for artificialy drained soils in Illinois. ASAE Paper No. 88-2617. St. Joseph, MI: ASAE.

Easterling, D., \& Karl, T. (2001). Climate change impacts on the United States: The potential consequences of climate variability and change. In Prepared for the U.S. Global Change Research Program (pp. 52-57). Cambridge, U.K.: Cambridge University Press.

Gao, P., Li, P., Zhao, B., Xu, R., Zhao, G., Sun, W., \& Mu, X. (2017). Use of double mass curves in hydrologic benefit evaluations. Hydrol. Process., 31(26), 4639-4646. https://doi.org/10.1002/hyp.11377

Hidalgo, H. G., Dettinger, M. D., \& Cayan, D. R. (2008). Downscaling with constructed analogues: Daily precipitation and temperature fields over the United States. California Energy Commission, PIER energy related environmental research. CEC-500-2007-123.

IPCC. (2014). Climate Change 2014: Impacts, adaptation and vulnerability. Part B: Regional aspects: Contribution of Working Group II to the Fifth Assessment Report of the Intergovernmental Panel on Climate Change. Cambridge: Cambridge University Press.

https://doi.org/10.1017/CBO9781107415416

Kale, S. (2011). Estimating effects of drainage design parameters on crop yields under irrigated lands using DRAINMOD. Scientific Rer. Essays, 14, 2955-2963.

Kalita, P. K., Cooke, R. A., Anderson, S. M., Hirschi, M. C., \& Mitchell, J. K. (2007). Subsurface drainage and water quality: The Illinois experience. Trans. ASABE, 50(5), 1651-1656. https://doi.org/10.13031/2013.23963

Knutti, R., Masson, D., \& Gettelman, A. (2013). Climate model genealogy: Generation CMIP5 and how we got there. Geophys. Res. Letters, 40(6), 1194-1199. https://doi.org/10.1002/grl.50256

Melillo, J., Richmond, T. C., \& Yohe, G. W. (2014). Highlights of climate change impacts in the United States: The third national climate assessment. Washington, DC: U.S. Global Change Research Program. Retrieved from http://s3.amazonaws.com/nca2014/low/NCA3_Highlights_Low Res.pdf?download $=1$

Miao, C., Duan, Q., Sun, Q., Huang, Y., Kong, D., Yang, T.,... Gong, W. (2014). Assessment of CMIP5 climate models and projected temperature changes over Northern Eurasia. Environ. Res. Letters, 9(5), 055007. https://doi.org/10.1088/17489326/9/5/055007

Nasrollahi, N., AghaKouchak, A., Cheng, L., Damberg, L., Phillips, T. J., Miao, C.,... Sorooshian, S. (2015). How well do CMIP5 climate simulations replicate historical trends and patterns of meteorological droughts? Water Resour. Res., 51(4), 2847-2864. https://doi.org/10.1002/2014wr016318

NCAR. (2013). The climate data guide: Taylor diagrams. National Center for Atmospheric Research. Retrieved from https://climatedataguide.ucar.edu/climate-data-tools-andanalysis/taylor-diagrams

Palmer, W. C., \& Havens, A. V. (1958). A graphical technique for determining evapotranspiration by the Thornthwaite method. Monthly Weather Rev., 86(4), 123-128. https://doi.org/10.1175/15200493(1958)086<0123:agtfde $>2.0 . c 0 ; 2$
Reclamation. (2013). Downscaled CMIP3 and CMIP5 climate and hydrology projections: Release of downscaled CMIP5 climate projections, comparison with preceding information, and summary of user needs. Denver, CO: U.S. Department of the Interior, Bureau of Reclamation, Technical Services Center. Retrieved from https://gdodcp.ucllnl.org/downscaled_cmip_projections/dcpInterface.html

Sanford, W. E., \& Selnick, D. L. (2012). Estimation of evapotranspiration across the conterminous United States using a regression with climate and land-cover data. JAWRA, 49(1), 217-230. https://doi.org/10.1111/jawr.12010

Schaap, M. G., Leij, F. J. and van Genuchten, M. Th. 2001. Rosetta: A computer program for estimating soil hydraulic parameters with hierarchical pedotransfer functions.J.Hydrol.251: 163-176.

Searcy, J. K., \& Hardison, C. H. (1960). Double-mass curves. U.S. Geological Survey Water-Supply Paper 1541-B, 31-66. Retrieved from https://pubs.usgs.gov/wsp/1541b/report.pdf

Singh, R., Helmers, M. J., Kaleita, A. L., \& Takle, E. S. (2009). Potential impact of climate change on subsurface drainage in Iowa's subsurface drained landscapes. J. Irrig. Drain. Eng., 135(4), 459-466. https://doi.org/10.1061/(ASCE)IR.19434774.0000009

Skaggs, R. W. (1981). Methods for design and evaluation of drainage-water management systems for soils with high water tables. DRAINMOD reference report. Washington, DC: USDASCS. Retrieved from https://www.bae.ncsu.edu/agriculturalwater-management/drainmod/manuals/

Skaggs, R. W. (2017). Coefficients for quantifying subsurface drainage rates. Appl. Eng. Agric., 33(6), 793-799. https://doi.org/10.13031/aea.12302

Skaggs, R. W., \& Murugaboopathi, C. (1994). Drainage and subsurface water management. In Management of water use in agriculture (p. 115). New York, NY: Springer-Verlag Berlin Heidelberg. https://doi.org/10.1007/978-3-642-78562-7 5

Skaggs, R. W., Breve, M. A., \& Gilliam, J. W. (1994). Hydrologic and water quality impacts of agricultural drainage. Critical Rev. Environ. Sci. Technol., 24(1), 1-32. https://doi.org/10.1080/10643389409388459

Skaggs, R. W., Fausey, N. R., \& Evans, R. O. (2012). Drainage water management. JSWC, 67(6), 167A-172A. https://doi.org/10.2489/jswc.67.6.167A

Southworth, J., Randolph, J. C., Habeck, M., Doering, O. C., Pfeifer, R. A., Rao, D. G., \& Johnston, J. J. (2000). Consequences of future climate change and changing climate variability on maize yields in the midwestern United States. Agric. Ecosyst. Environ., 82(1), 139-158. https://doi.org/10.1016/S0167-8809(00)00223-1

Taylor, K. E. (2001). Summarizing multiple aspects of model performance in a single diagram. J. Geophys. Res.: Atmospheres, 106(D7), 7183-7192. https://doi.org/10.1029/2000jd900719

Thorp, K. R., Jaynes, D. B., \& Malone, R. W. (2008). Simulating the long-term performance of drainage water management across the midwestern United States. Trans. ASABE, 51(3), 961976. https://doi.org/10.13031/2013.24534

UCS (Union of Concerned Scientists). (2009). Confronting climate change In the U.S. Midwest. Retrieved from https://www.ucsusa.org/sites/default/files/legacy/assets/documen ts/global_warming/climate-change-illinois.pdf

USDA. (2017). Web soil survey. USDA NRCS. Retrieved from https://www.nrcs.usda.gov/wps/portal/nrcs/surveylist/soils/surve $\mathrm{y} /$ state/?stateId $=\mathrm{IL}$ 
USDA-NASS. (2017). Illinois crop production. Washington, DC: USDA-NASS. Retrieved from

https://www.nass.usda.gov/Statistics_by_State/Illinois/Publicati ons/Current_News_Release/2017/20170810-

IL Crop Production.pdf

USDA-NRCS. (2017). NRCS field office technical guide, section IV. Conservation practice standard, drainage water management (code 554). Washington, DC: USDA-NRCS. Retrieved from https://efotg.sc.egov.usda.gov/references/public/IL/IL554_5-3117.pdf

Winkler, J. A., Guentchev, G. S., Liszewska, M., Perdinan, \& Tan, P.-N. (2011). Climate scenario development and applications for local/regional climate change impact assessments: An overview for the non-climate scientist. Geography Compass, 5(6), 301328. https://doi.org/10.1111/j.1749-8198.2011.00426.x
Wuebbles, D. J., \& Hayhoe, K. (2004). Climate change projections for the United States Midwest. Mitigation Adaptation Strategies Global Change, 9(4), 335-363. https://doi.org/10.1023/B:MITI.0000038843.73424.de

Yokohata, T., Annan, J. D., Collins, M., Jackson, C. S., Tobis, M., Webb, M. J., \& Hargreaves, J. C. (2011). Reliability of multimodel and structurally different single-model ensembles. Climate Dyn., 39(3), 599-616. https://doi.org/10.1007/s00382011-1203-1

Youssef, M. A., Abdelbaki, A. M., Negm, L. M., Skaggs, R. W., Thorp, K. R., \& Jaynes, D. B. (2018). DRAINMOD-simulated performance of controlled drainage across the U.S. Midwest. Agric. Water Manag., 197, 54-66.

https://doi.org/10.1016/j.agwat.2017.11.012 